\title{
New deep-water brachiopod resilient assemblage from the South-Iberian Palaeomargin (Western Tethys) and its significance for the brachiopod adaptive strategies around the Early Toarcian Mass Extinction Event
}

\author{
José F. BAEZA-CARRATALÁ, MATíAs REOLID \& FERNANDO GARCÍA JORAL
}

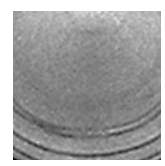

\begin{abstract}
The Pliensbachian-Toarcian transition was a period of changes in long-term environmental conditions leading up to the Early Toarcian Mass Extinction Event (ETMEE), which resulted in a noticeable extinction and turnover in the marine biota. The westernmost Tethyan basins, especially the peri-Iberian platforms, provide an exceptional brachiopod record to better understand the adaptive strategies and the severe ecological effects of these faunas within the marine ecosystems. This event marks a critical interval in the evolutionary history of the Phylum Brachiopoda as two orders, the Athyridida and Spiriferinida, became extinct. Evolutionary patterns displayed by several taxa from these groups and some rhynchonellids typifying deep-water habitats are analyzed across this biotic crisis spanning several Mediterranean and NW-European basins. New work performed in La Cerradura section, a deep pelagic trough from the South-Iberian palaeomargin, reveals two new taxa (Koninckodonta sumuntanensis and Atychorhynchia falsiorigo) herein described. This newly documented fauna supports pre-extinction dwarfing and resilience in deep refugia linked to the ETMEE, and an episode of speciation which is interpreted in terms of a pre-extinction radiation. In the ETMEE repopulation phase an opportunistic strategy occurs typified by Soaresirhynchia bouchardi, and a case of homoplasy involving post-extinction pioneers (Elvis taxon) is detected. Similar adaptive strategies occurred associated with other mass extinctions such as the Permian/Triassic and the Cretaceous/Paleocene events, supporting a possible standard pattern in the response of the brachiopod fauna to such biotic crises and shedding light on the ecological effects of the mass extinction events. $\bullet$ Key words: Jurassic, Brachiopods, Western Tethys, Early Toarcian Mass Extinction, adaptive strategies.
\end{abstract}

BAEZA-CARratalÁ, J.F., REOlid, M. \& GARCÍA Joral, F. 2017. New deep-water brachiopod resilient assemblage from the South-Iberian Palaeomargin (Western Tethys) and its significance for the brachiopod adaptive strategies around the Early Toarcian Mass Extinction Event. Bulletin of Geosciences 92(2), 233-256 (11 figures, 1 table). Czech Geological Survey, Prague. ISSN 1214-1119. Manuscript recevived September 9, 2016; accepted in revised form May 16, 2017; published online June 30, 2017; issued June 30, 2017.

José F. Baeza-Carratalá, Departamento de Ciencias de la Tierra y Medio Ambiente, Universidad de Alicante. Apdo. 99, San Vicente del Raspeig, 03080, Alicante, Spain; jf.baeza@ ua.es•Matías Reolid, Departamento de Geología y CEACT, Universidad de Jaén, 23071, Jaén, Spain; mreolid@ujaen.es•Departamento de Paleontología, Facultad de Ciencias Geológicas, Universidad Complutense. C/José Antonio Novais, 2; 28040, Madrid, Spain; fgjoral@ucm.es

The Early Toarcian Mass Extinction Event (ETMEE) was one of the most important environmental perturbations of the Mesozoic which had a dramatic impact on the marine benthic and nekto-planktic biota (e.g. Hallam 1986, 1987; Little \& Benton 1995; Harries \& Little 1999; McArthur et al. 2000; Bailey et al. 2003; Wignall et al. 2005; Dera et al. 2010). The mass extinction was experienced by many organisms living at various levels within the water column. This includes benthic groups, such as bivalves (Aberhan \& Fürsich 1997), brachiopods (Vörös 2002, García Joral et al. 2011, Baeza-Carratalá et al. 2015), cnidarians (Lathui- lière \& Marchal 2009), foraminifera (Nikitenko \& Mickey 2004, Zakharov et al. 2006) and ostracodes (Arias 2009); as well as nekto-benthic/nektonic ammonites (Macchioni \& Cecca 2002, Cecca \& Macchioni 2004, Dera et al. 2010) and planktic forms, such as dinoflagellates (Bucefalo Palliani et al. 2002).

Some previous authors suggested that the ETMEE was actually a multi-phased event ( $c f$. Little 1996, Macchioni \& Cecca 2002, Wignall \& Bond 2008, Dera et al. 2010, Caruthers et al. 2013, Arias 2013, Rita et al. 2016) the onset of which is detected in the late Pliensbachian-earliest 
Toarcian, with the main phase coinciding with the early Toarcian Oceanic Anoxic Event (T-OAE; established in the westernmost Tethys within the serpentinum/levisoni Zone for the Sub-Mediterranean/Mediterranean Domain respectively) as a result of a period of changes in long-term environmental conditions prior to this event ( $c f$. Harries \& Little 1999, Dera et al. 2010, Suan et al. 2010, Gómez \& Goy 2011, García Joral et al. 2011). This relatively long phase represents the so-called "extinction interval" where diverse environmental changes or pulses occurred.

After the significant compositional turnover that the end-Triassic extinction event produced in the brachiopod communities (Hallam 1990, 1996; Tomašových \& Siblík 2007) with severe effects on several clades as spiriferinids and athyridids (Jablonski 2002, Vörös et al. 2016), the ETMEE was an important interval in brachiopod evolutionary history as these two (i.e. the Athyridida and Spiriferinida) of the five orders known prior to the event became extinct (e.g. Vörös 2002). Amidst the Early Jurassic brachiopods, the profuse record and extinction of the koninckinid fauna can be used as a precursor signal of the main biotic crisis event within this multi-phased extinction interval (Baeza-Carratalá et al. 2015). The present work analyzes the evolutionary trends of several taxa belonging to these extinct and survivor groups in La Cerradura Section (CE section hereinafter), located in the South-Iberian palaeomargin, close to the Gondwana palaeomargin, with ocean dynamics influenced by the convergence of the Spanish Corridor connecting the Western Tethys and the Proto-Atlantic seaway. In this locality, koninckinid fauna is recorded together with spiriferinids and new taxa typifying deep-water habitats in the final phases of the extinction interval, providing new data on the adaptive response of brachiopods that can be a crucial key to better understanding the ecologic adaptive strategies in relation to this biotic crisis.

Globally, the ETMEE is typified by a crisis of carbonate production in shallow-marine settings, an increase in organic matter content and a negative carbon isotope excursion (Jenkyns \& Clayton 1997; Mattioli et al. 2004, 2009; Hesselbo et al. 2007; Suan et al. 2008; Hermoso et al. 2009; Al-Suwaidi et al. 2010, 2016; Littler et al. 2010; Caruthers et al. 2011). This event, so-called T-OAE (Toarcian Oceanic Anoxic Event) was originally considered as global on the basis of the prevailing record of organic-rich facies and anoxic conditions (Jenkyns 1988). However, the conditions recorded in deeper-water settings suggest considerable geographical variability (e.g. Gómez et al. 2008; Hermoso et al. 2009; Rodríguez-Tovar \& Reolid 2013; Reolid et al. 2014a, b). Recent analyses have documented the role of local and regional factors that overprint the typical pattern of the T-OAE (Braga et al. 1981; McArthur et al. 2008; Rodríguez-Tovar \& Uchman 2010; Reolid et al. 2013a, b; Rodríguez-Tovar \& Reolid 2013).

In the CE section, the main pulse of T-OAE was recorded in the lowermost serpentinum Zone, but with lower levels of total organic carbon (wt\% TOC) than other Western Tethyan sequences (Reolid et al. 2014a). There is some uncertainty on the precise timing of the event in CE, but as brachiopods occur above the levels where the main pulse of T-OAE is detected, this area could have been a deep water "refugia". Additionally, the record at CE contributes to enhanced analysis of an example of adaptive dwarfism in the extinction intervals in groups such as the koninckinids and spiriferinids, in contrast with the well-known Lilliput effect regarded as a post-extinction syndrome in the aftermath of the extinction boundaries.

\section{Geological setting}

The Early Jurassic brachiopods analyzed in this study were primarily derived from the External Subbetic (External Betic zones). The External Betic zones (Fig. 1) comprise the Prebetic and Subbetic, both made up of thick successions of Triassic to Miocene strata (Vera et al. 2004). The Prebetic rocks were deposited in shallow-marine shelfal, coastal plain and continental environments during the Jurassic and Cretaceous. During the Jurassic, the Subbetic was a relatively distal setting, characterized by pelagic swells with low rates of subsidence abutting subsiding central troughs (e.g. Braga et al. 1981, Reolid et al. 2015). Jurassic sedimentation in the External Subbetic is characterized by shallow shelf deposits in the lowermost Jurassic (Gavilán Formation), overlain by Pliensbachian-Aalenian hemipelagic facies of marls and marly limestones (Zegrí Formation).

The main fragmentation stage of the large carbonate platform occurred during the earliest Jurassic (García-Hernández et al. 1987, 1989; Vera 2001; Vera et al. 2004), when rocks of the Gavilán Formation were deposited. Blocks were tilted along a number of listric faults (Vera 2001), and those which experienced less subsidence became pelagic swells with condensed ammonitico rosso facies (e.g. Braga et al. 1981, Reolid et al. 2015). The differential block subsidence resulted in remarkable thickness variation (Vera et al. 2004).

Figure 1. Geological setting and stratigraphical succession studied. $\bullet$ A - situation of La Cerradura section in the context of the Betic Cordillera, Spain (modified after Vera et al. 2004). • B - geological map around the La Cerradura locality (modified after Roldán et al. 1991). • C - synthetic Lower Jurassic lithostratigraphical column from La Cerradura. $\bullet$ D - outcrop view of La Cerradura section showing the distribution of the ammonites chronozones. 

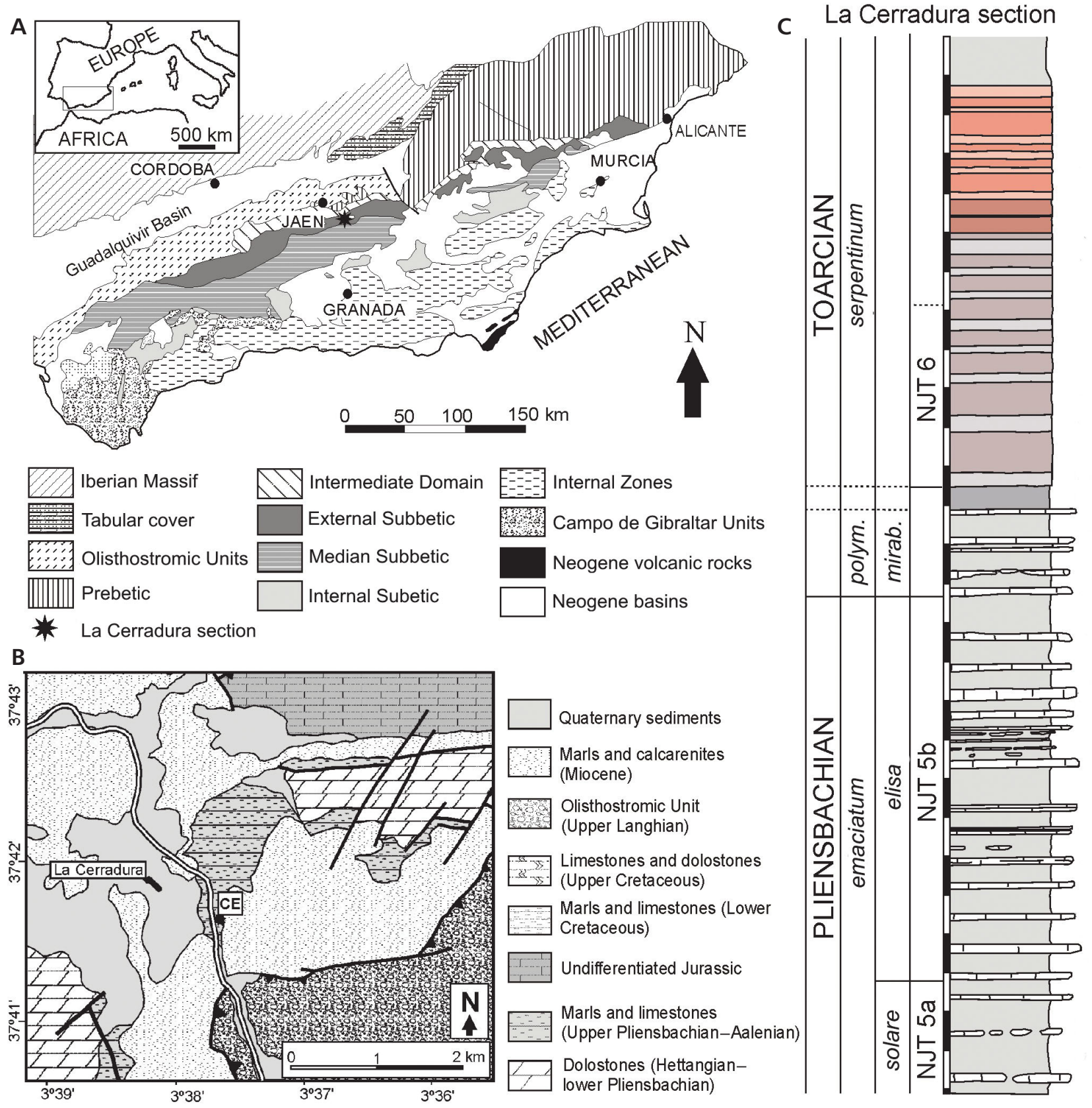

eogene basins

\section{B}

Quaternary sediments

Marls and calcarenites (Miocene)

3. Olisthostromic Unit (Upper Langhian)

Limestones and dolostones (Upper Cretaceous)

Marls and limestones (Lower Cretaceous)

Undifferentiated Jurassic

Marls and limestones

(Upper Pliensbachian-Aalenian)

Dolostones (Hettangian-

lower Pliensbachian)

D

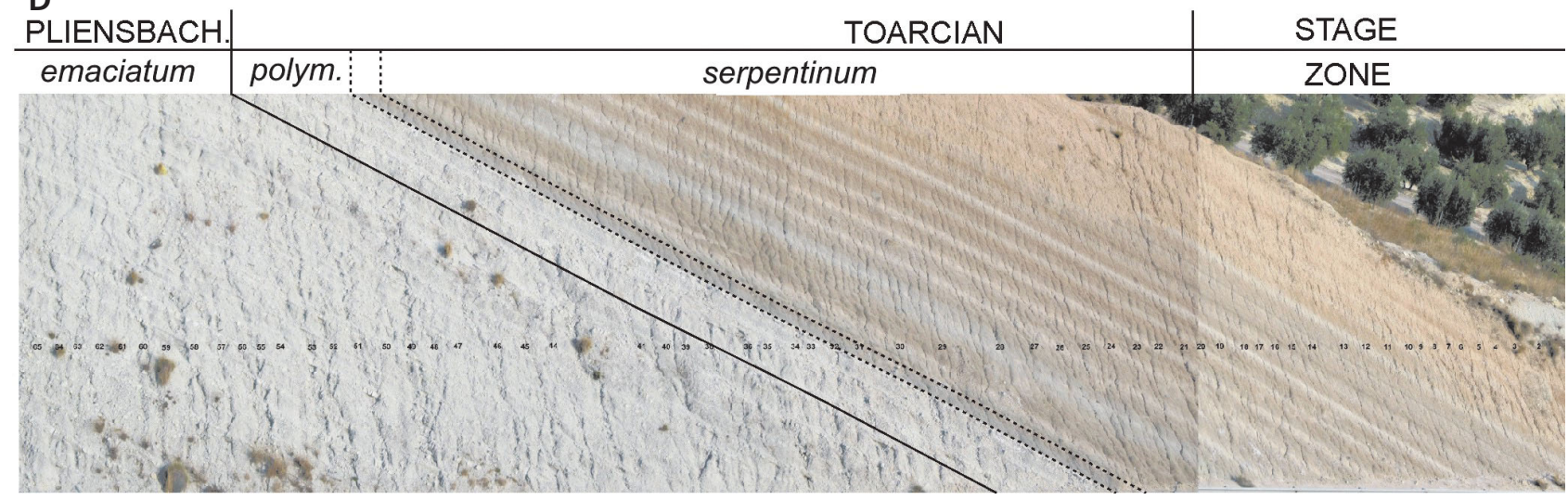




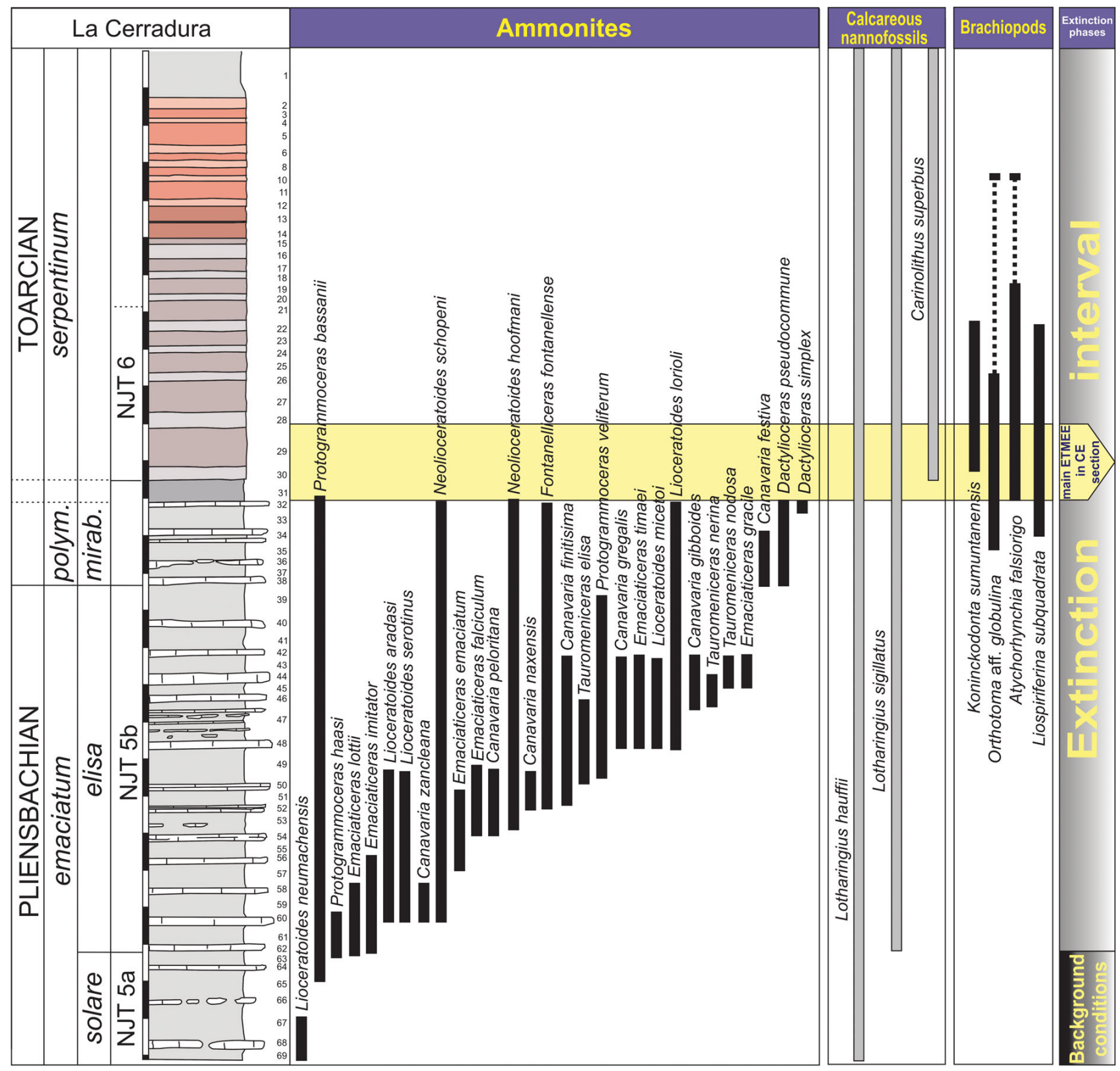

Figure 2. Brachiopod occurrences in La Cerradura section together with the ammonite and calcareous nannofossil distributions. The main early Toarcian Mass Extinction Event in La Cerradura is marked after Reolid et al. (2014a) on the basis of geochemical and palaeontological proxies within NJT-16 Zone. Extinction phases of the brachiopod fauna have been pointed out (sources for their establishment are cited in the text). Ammonite distribution is based on Braga (1983), Jiménez (1986) and Reolid et al. (2014a) and calcareous nannofossils in Reolid et al. (2014a).

New sampling in the External Subbetic has been carried out at the La Cerradura section $\left(37^{\circ} 41^{\prime} 47.8^{\prime \prime} \mathrm{N}\right.$; $3^{\circ} 37^{\prime} 57.6^{\prime \prime} \mathrm{W}$ ). The section (Fig. 1) is $15 \mathrm{~km}$ south of the Jaen City (Spain). Early studies of this area were carried out by Mouterde et al. (1971) and the ammonite fauna was primarily studied by Braga (1983) and Jiménez (1986). Recently, Sandoval et al. (2012) dealt with this section in a comprehensive study on the Toarcian Subbetic facies, mainly focused on ammonite and calcareous nannofossil bioevents.
The rocks comprising the CE section represent a pelagic marine setting with deep habitats below storm wave base in the South-Iberian palaeomargin, close to the Hispanic Corridor and the passage between the Western Tethys and the Proto-Atlantic seaway (Aberhan 2001, Bailey et al. 2003), at a palaeolatitude of $\sim 20^{\circ} \mathrm{N}$ (Jiménez et al. 1996, Rodríguez-Tovar \& Reolid 2013). The Zegrí Formation exposed at CE section was deposited in a subsiding area with an expanded sedimentation and a greater cumulative thickness (Reolid et al. 2014a). 


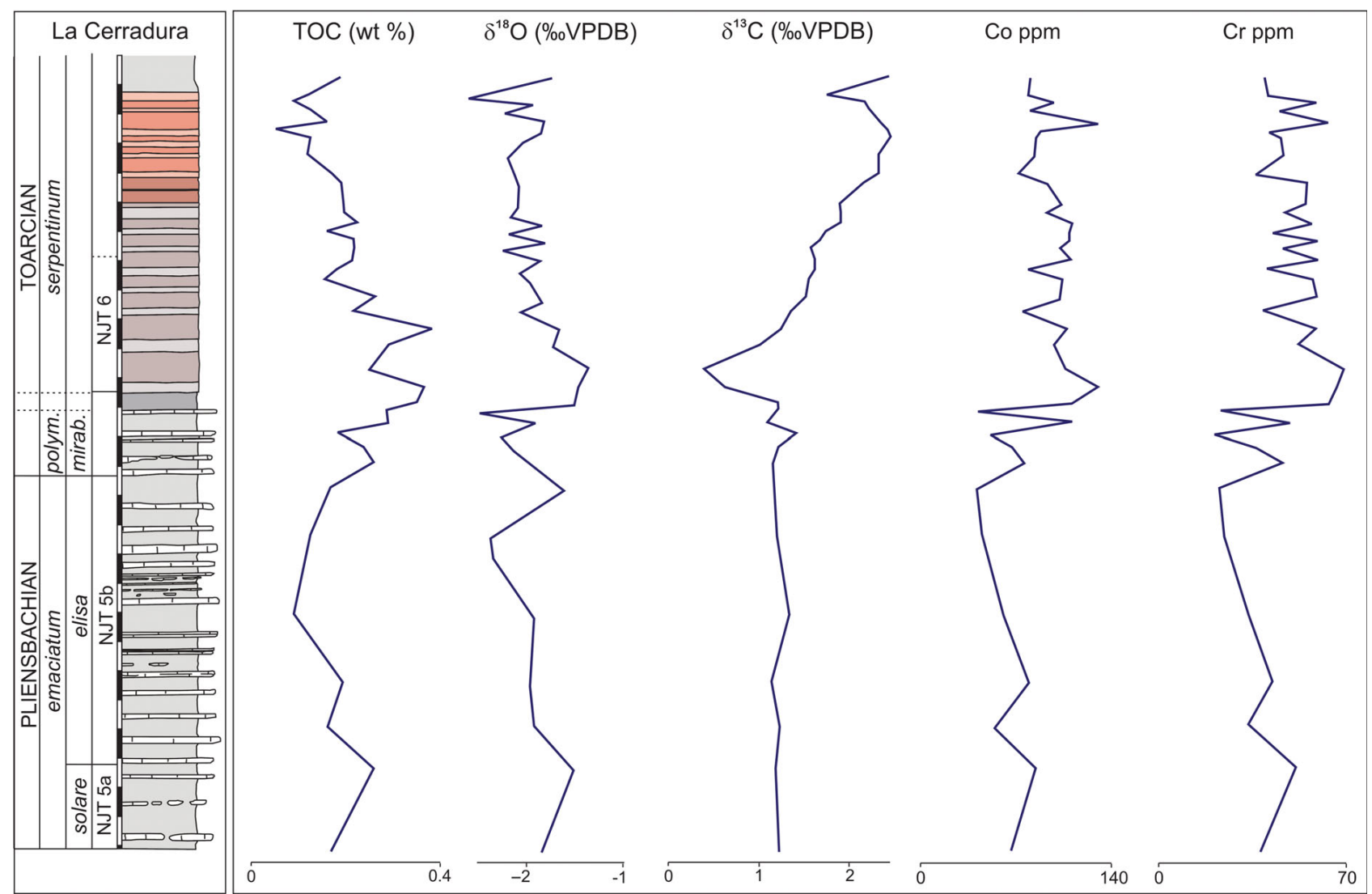

Figure 3. Geochemical proxies. Stratigraphic distribution in the La Cerradura section of the total organic carbon (TOC), $\delta^{18} \mathrm{O}$ and $\delta^{13} \mathrm{C}$ from bulk sample, and content of redox sensitive elements (ppm).

The CE section is composed of $27.5 \mathrm{~m}$ of marl-marly limestone rhythmite and $12 \mathrm{~m}$ of dark marls (Fig. 1, 2). The marly limestone succession consists of mudstone and occasional wackestone beds with sporadic mollusc bioclasts. The marly layers are rich in illite, smectite and chlorite (Caniço et al. 2015). Recently, Reolid et al. (2014a) identified the early Toarcian Oceanic Anoxic Event in the CE stratigraphic column by the increase in redox sensitive elements, total organic carbon (TOC) and total sulfur (TS), the record of a negative carbon isotopic excursion (CIE), changes in calcareous nannofossils, and absence of benthic remains and trace fossils. This interval corresponds to the first $60 \mathrm{~cm}$ above the top of the marl-limestone rhythmite (Figs 2, 3). Brachiopod-bearing levels are found in both marl-marly limestone rhythmite and dark marls beds (levels 35 to 10 in Fig. 2), extending above the main T-OAE pulse recorded by Reolid et al. (2014a).

\section{Material and methods}

New bed-by-bed sampling in the CE section has been exhaustively carried out to achieve a high-resolution record, resulting 112 newly collected brachiopods. Mean biomet- ric parameters (length, width, thickness) were measured for complete specimens. Generic assignments follow published determinations mainly in the Treatise (Kaesler \& Selden, 1997-2007). The internal structure of brachiopods was studied using the conventional method of taking acetate peels after making transverse serial sections. The distance between serial sections was $0.1 \mathrm{~mm}$. All the sectioned and figured specimens are deposited in the Departamento de Ciencias de la Tierra y del Medio Ambiente (University of Alicante, Spain).

The ammonite zonal/subzonal scheme follows the commonly used zonation for the Betic Range, based on the standard proposed by Cariou \& Hantzpergue (1997) for the Mediterranean Domain, supplemented by biochronological data from Braga (1983) and Jiménez \& Rivas (1979). Their equivalent in the Sub-Mediterranean European Domain has been pointed out when necessary for correlations (Fig. 4B). The Pliensbachian and Toarcian ammonites in the CE section were studied by Braga (1983) and Jiménez (1986), respectively. Coccolith distributions (Reolid et al. 2014a) allow calibration according to the scheme of Mattioli \& Erba (1999) for the South-Tethyan region. Other recent biochronological data (Mattioli et al. 2004, 2013) are also applied. 


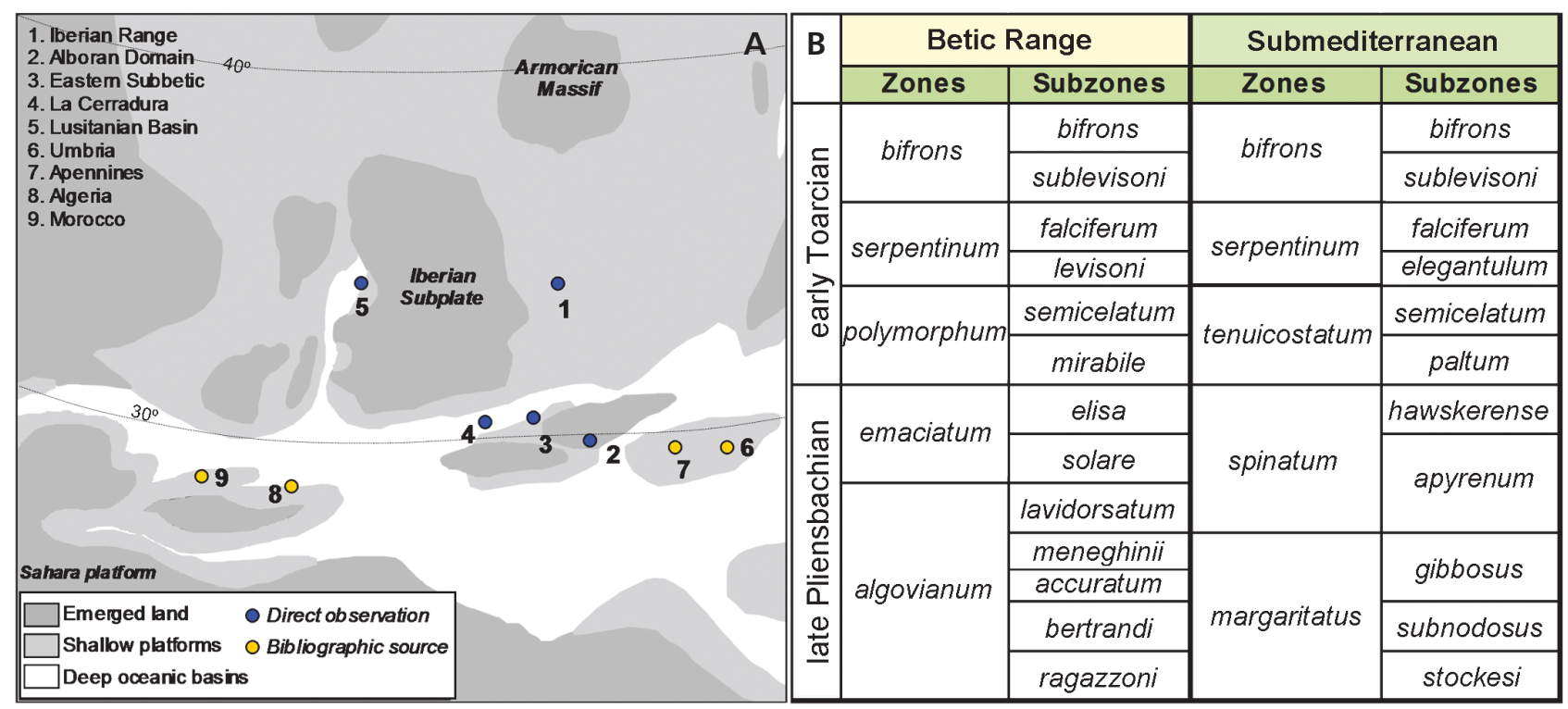

Figure 4. Palaeogeographical and chronostratigraphical context of the analysis. $\bullet$ A - situation of the brachiopod fauna datasets (bibliographic/directly examined sources) referred to in this study, plotted on an Early Jurassic palaeomap, slightly modified after Bassoullet et al. (1993). • B - sketch showing the biochronozones commonly used for the Betic Range, and their equivalent in the Sub-Mediterranean Domain to perform correlations.

Stable isotopic records from Reolid et al. (2014a) are used for determining the position of the negative CIE in the section. In addition, the analysis of redox sensitive trace elements such as $\mathrm{Co}, \mathrm{Cr}, \mathrm{Cu}$, Th and $\mathrm{U}$, which are less soluble under reducing conditions and enriched in the sediment under suboxic and anoxic conditions, constituted a tool for confirming oxygen reducing biofacies during the negative CIE (Reolid et al. 2014a). Total organic carbon content (TOC) was calculated as percentage of the sample weight.

A comparative analysis was performed after review of the dataset from several Mediterranean and NW-European basins; mainly by means of the newly collected brachiopods in the CE section, 503 athyridid and spiriferinid specimens from the easternmost Subbetic area (Baeza-Carratalá 2008, 2013), located $300 \mathrm{~km}$ eastward from CE, and several bibliographical sources of Mediterranean (Pozza \& Bagaglia 2001, Vörös 2003), and Portuguese (ComasRengifo et al. 2013, 2015) koninckinid faunas. This latter material was directly examined by one of the authors (FGJ). Previous data from the Internal Betic Zone (Baeza-Carratalá et al. 2011) and the Iberian Range (García Joral et al. 2011) have also been taken into account
(Fig. 4A). These brachiopod faunas were analysed through cluster analysis computed using the Jaccard similarity coefficient from the PAST software package (Hammer et al. 2001). Paleobiogeographic categorization of biochores follows the nomenclature propsosed by Westermann (2000), subsequently adapted for the brachiopod fauna by several authors (e.g. Manceñido 2002, Vörös 2016).

\section{Compositional analysis of the brachiopod-bearing deposits in the CE section}

Taxonomic analysis performed in the brachiopod fauna from the CE section reveals the occurrence of an assemblage recorded around the ETMEE consisting of Liospiriferina subquadrata (Seguenza, 1885), Orthotoma aff. globulina (Davidson, 1851), Koninckodonta sumuntanensis nov. sp. and Atychorhynchia falsiorigo gen. et sp. nov. (Fig. 5). The two new taxa constituting the faunal core of this assemblage must be emphasized since they are herein recorded and formally described for the first time:

Figure 5. Some representative taxa of the brachiopod assemblage from La Cerradura. All specimens were coated with magnesium oxide. Images from 1 to 13 are arranged thus in (a) dorsal, (b) lateral, and (c) anterior views. Images from 13 to 20 are ordered in (a) dorsal, (b) anterior, (c) ventral, and (d) lateral views. • 1-4 - Atychorhynchia falsiorigo gen. et sp. nov.; 1 - specimen CE28.Rh1 (holotype); 2 - specimen CE28.Rh2; 3 - specimen CE19.Rh1; 4 - specimen CE19.Rh2 (2-4 with severe diagenetic distortion). $•$ 5-6 - Orthotoma aff. globulina (Davidson): 5 - specimen CE32.O1; 6 - specimen CE26.O1. • 7-13 - Liospiriferina subquadrata (Seguenza); 7 - specimen CE27b.LS1; 8 - specimen CE24.LS2; 9 - specimen CE27.LS1; 10 - specimen CE27.LS2; 11 - specimen CE27.LS3; 12 - specimen CE26.LS1; 13 - specimen CE24.LS1. •14-20 - Koninckodonta sumuntanensis sp. nov.; 14 - specimen CE28.K1 (holotype); 15 - specimen CE22.K1; 16 - specimen CE28.K2; 17 - specimen CE28.K3; 18 - specimen CE29B.K1; 19 - specimen CE29B.K2; 20 - specimen CE26.K1. 


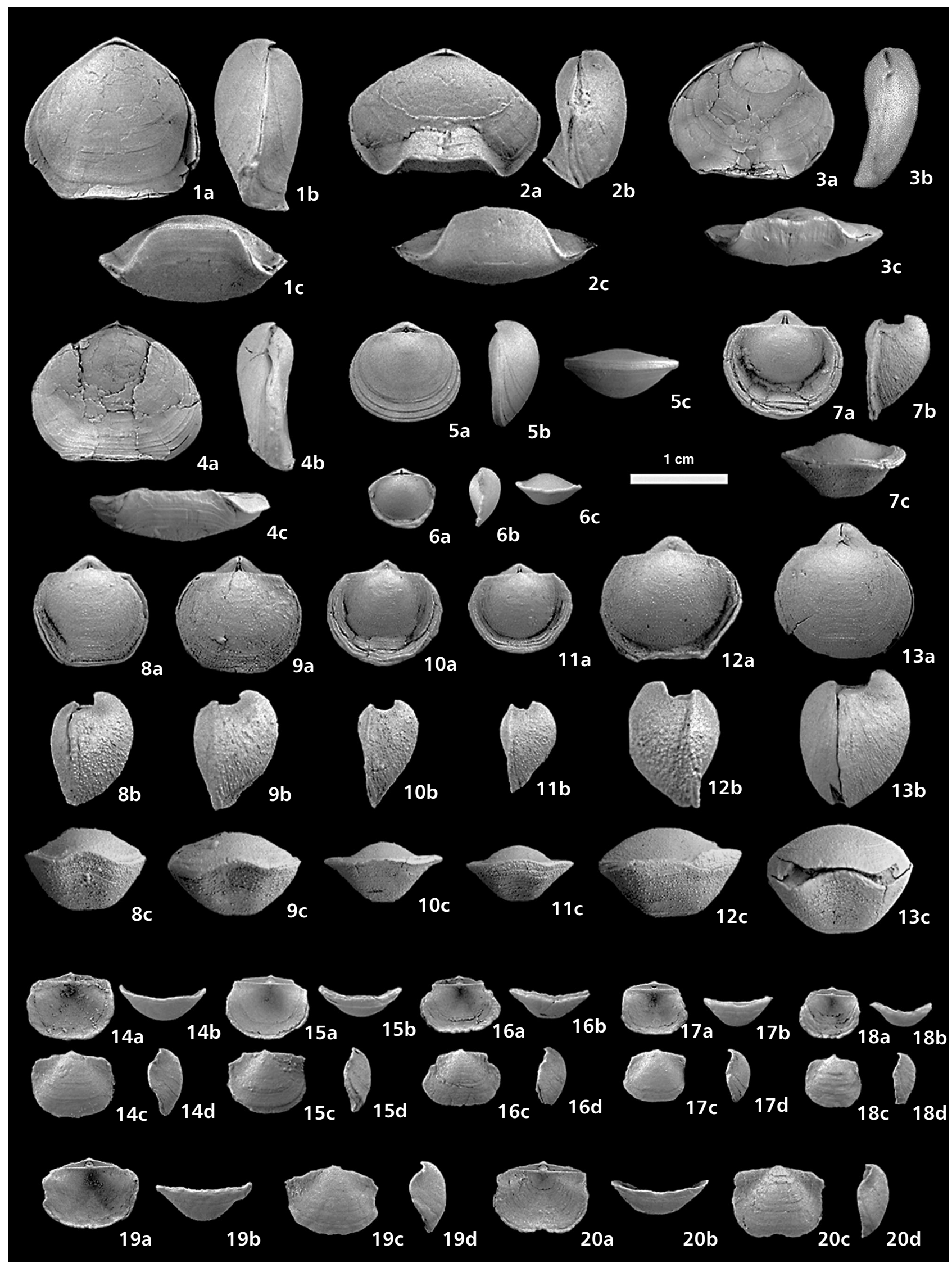


Order Rhynchonellida Kuhn, 1949

Superfamily Norelloidea Ager, 1959

Family Norellidae Ager, 1959

Subfamily Norellinae Ager, 1959

\section{Genus Atychorhynchia gen. nov.}

Type Species. - Atychorhynchia falsiorigo nov. sp.

Derivation of name. - From [atycha]: Greek = unfortunate.

Diagnosis. - Smooth subpentagonal Norellidae with rather flat valves and short and pointed beak containing a minute foramen. Anterior commissure clearly uniplicate. Very short dental plates fused to the ventral valve; dorsal median septum and septalium absent. Short arcuiform crura.

Remarks. - Internal and external features suggest the arrangement of these rhynchonellids within the Family Norellidae Ager, 1959 and almost certainly into the Subfamily Norellinae Ager, 1959, but they cannot be assigned to any genus currently belonging to this Subfamily. Their similarity is obvious, except for the distinctive sulcation present in most of the representatives. In fact, based on external morphology Atychorhynchia would be better related with the smooth and uniplicate representatives of this Subfamily such as the Triassic-Early Jurassic Austriellula, which was placed with uncertainty into the Norellinae in the revised Treatise (Savage et al. 2002).

Occurrence. - Late Pliensbachian-early Toarcian (polymorphum-serpentinum chronozones).

Atychorhynchia falsiorigo sp. nov. Figures 5.1-5.4, 6, 7

Holotype. - CE28.Rh1. Dimensions (in mm): L: 17.01; W: 17.79; T: 8.63. Deposited in the Departamento de Ciencias de la Tierra y del Medio Ambiente (University of Alicante, Spain).

Type locality. - La Cerradura, Jaén Province, Betic Cordillera, Spain.

Derivation of name. $-[$ falsum, $-i] ;[$ origo $]$ : Latin $=$ false, failed; origin. It is referred to its condition of "failed crisis progenitor" leading the repopulation phase in the aftermath of the Early Toarcian Mass Extinction Event.

Diagnosis. - As for genus.

Description. - Medium-sized shells (Fig. 7), biconvex with rather flat valves and triangular to subpentagonal outline.
Specimens are wider than long, the maximum width lying in the mid-length and the maximum convexity shifted toward the posterior third. The beak is very short and pointed and shows a minute and mesothyrid foramen with well-developed beak ridges. The lateral commissure is straight and the anterior commissure is uniplicate with a trapezoidal dorsal median fold. The shells are usually smooth but there are rare forms with anteromarginal rounded plicae. They often display spaced growth lines. The specimens frequently show diagenetic distortions (compressed and flattened lateral profiles).

Internal structure (Fig. 6): small pedicle cavity with pedicle collar present, very short dental plates fused to the ventral valve and hinge teeth slightly crenulated and inserted in broad sockets parallel to the commissural plane. Hinge plates dorsally oriented. Dorsal median septum and septalium are absent. Crura are short. First stages of the crural architecture have a dorsal development acquiring distally a clear ventral arcuiform progression.

Remarks. - Most of the external features of A. falsiorigo such as the biconvex profile, smooth uniplicate form, with subpentagonal outline, are similar to those shown by the smooth (or slightly plicate) varieties of Soaresirhynchia bouchardi. Essential differences can be found in the beak features, very short and pointed in A. falsiorigo and the major convexity of the valves in $S$. bouchardi. Crural development is also different, arcuiform in A. falsiorigo as opposed to hamiform-subfalciform in S. bouchardi. The same is applicable for the classical smooth and uniplicate Pliensbachian representatives of the genus Apringia, recently revised and split into several genera by Vörös (2009), all showing characteristic hamiform-subfalciform crura.

Occurrence. - Zegrí Fm., late Pliensbachian-early Toarcian (polymorphum-serpentinum chronozones).

Order Athyridida Boucot, Johnson \& Staton, 1964

Suborder Koninckinidina Harper, 1993

Superfamily Koninckinoidea Davidson, 1853

Family Koninckinidae Davidson, 1853

\section{Genus Koninckodonta Bittner, 1893}

\section{Koninckodonta sumuntanensis sp. nov.} Figures 5.14-5.20, 7

Holotype. - CE28.K1. Dimensions (in mm): L: 6.45; W: 8.20; T: 3.20. Deposited in the Departamento de Ciencias de la Tierra y del Medio Ambiente (University of Alicante, Spain). 

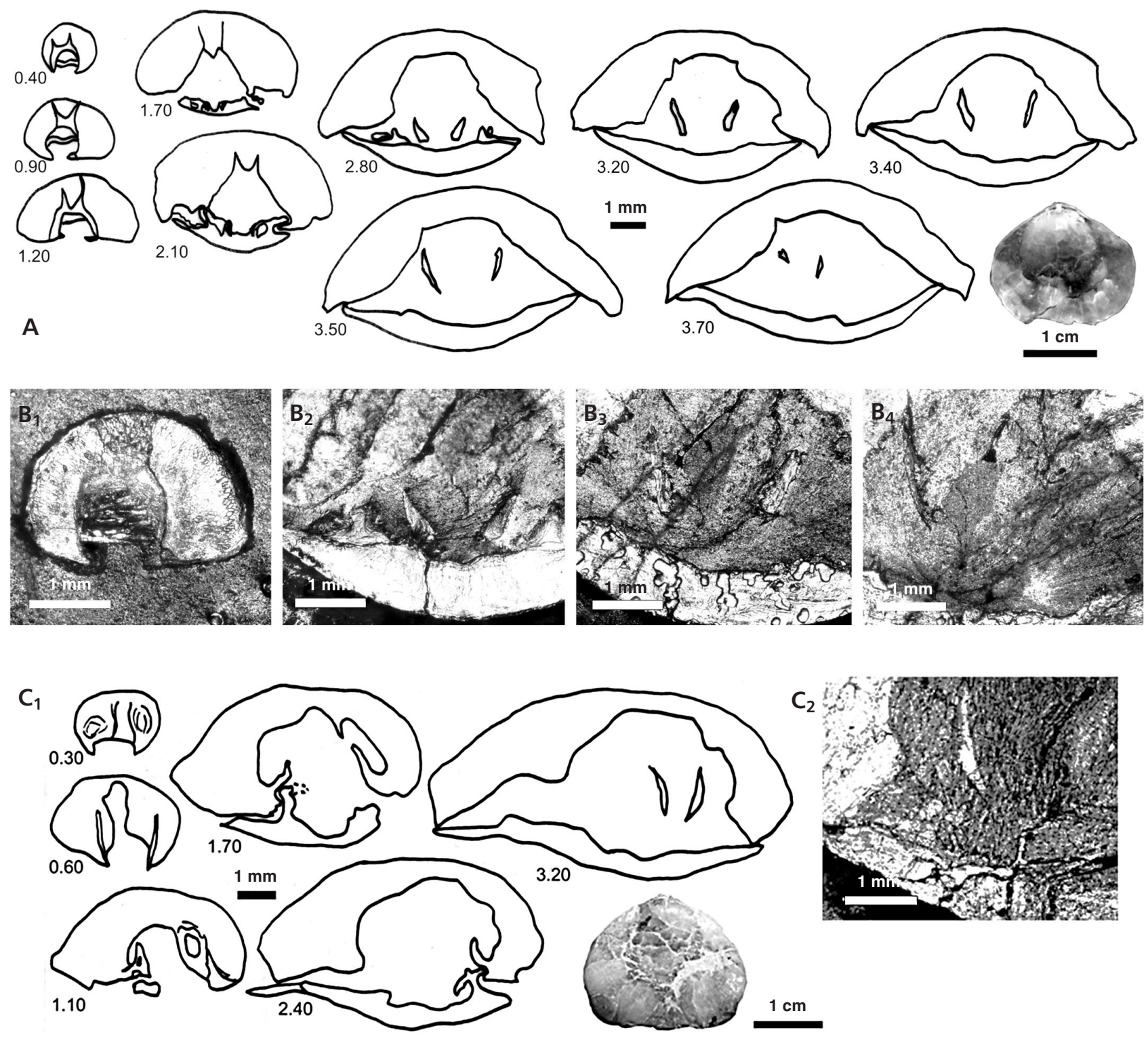

Figure 6. Internal structure of Atychorhynchia falsiorigo gen. et sp. nov. • A - transverse serial sections through specimen CE28b.Rh1 (distance from the apex in mm). B1-B4 - photomicrographs of acetate peels from specimen CE28b.Rh1; B1 - section at $0.40 \mathrm{~mm}$ from the apex, showing the delthyrial cavity with vestiges of the pedicle collar; B2, B3 - sections at 2.80 and $3.20 \mathrm{~mm}$ from the apex, respectively showing the initial stages of crural development, close to the brachial valve; $\mathrm{B} 4$ - section at $3.50 \mathrm{~mm}$ from the apex, showing arcuiform crural development. $\bullet \mathrm{C} 1$ - transverse serial sections through specimen CE10.Rh1 (distance from the apex in $\mathrm{mm}$ ). $\bullet \mathrm{C} 2$ - photomicrograph of acetate peel at $3.20 \mathrm{~mm}$ from the apex in specimen CE28b.Rh1 showing a detailed view of the arcuiform crura.

Type locality. - La Cerradura, Jaén Province, Betic Cordillera, Spain.

Derivation of name. - from Sumuntan, the ancient toponym of Sierra Mágina, the region where this species is recorded for the first time.

Diagnosis. - Smooth small-sized shells with subrectangular outline, wider than long. Wing-shaped and curved posterior margins and large cardinal areas. The beak is pointed and sharp. Anterior commissure with a wide to vague sinus.
Description. - Small-sized Koninckodonta (Fig. 7) with subquadrate to rectangular outline, wider than long and with maximum convexity near the mid-length or slightly shifted toward the anterior third of the shell. Hinge margins and cardinal areas large and widening-expanded. It shows distinctive posterolateral expansions, giving a wing-shaped outline to the posterior margin. These winged extensions are well-delimited due to their ventral curving. The beak is nearly pointed and sharp and the shell often shows densely packed growth lines, mainly in the anterior third. The anterior commissure shows a wide sinus, which in some specimens is nearly indiscernible. 
Remarks. - The subquadrate-rectangular outline of this taxon and their wing-shaped posterior extensions assign this species to the broad group of specimens attributed to $K$. davidsoni in the Western Tethys as a whole. Its shape is comparable to that in species such as $K$. davidsoni, K. geyeri and $K$. auriculata. However, $K$. sumuntanensis has the cardinal line and posterior margins less straight than $K$. geyeri and $K$. davidsoni, also showing a more convex ventral valve. The closest affinity is found to representatives of $K$. auriculata (Vörös 2003), due to their similar wing-shaped profile, tilted towards the ventral valve, but the beak is rather massive and incurved in $K$. auriculata while it is sharper and pointed in $K$. sumuntanensis, the latter also showing a wide anterior sinus, not present in $K$. auriculata. Also remarkable is the difference in size, the length of $K$. auriculata being more than twice that of $K$. sumuntanensis.

Occurrence. - Zegrí Fm., late Pliensbachian-early Toarcian (polymorphum-serpentinum chronozones).

\section{Record of the ETMEE in the CE section}

Recent works explain the ETMEE as a pronounced biotic crisis consisting in a multi-phased interval with episodes of changing environmental conditions, which started in the late spinatum Chronozone up to the extinction boundary within the early serpentinum Chronozone. In the expanded hemipelagic facies of the CE section, Reolid et al. (2014a) reported the main T-OAE pulse by the increase in redox sensitive elements, TOC and TS, the record of a negative $\mathrm{CIE}$, calcareous nannofossil changes and a barren interval of benthic remains.

The geochemical proxies typifying the event in this section indicate an abrupt change at the beginning of the dark marly interval (Fig. 3) with decreasing values of carbonate content and increasing TOC values $(0.4 \% \mathrm{wt}$, but low if it is compared with the Central and North-European outcrops, lying in the lower range of those recorded in the Tethyan Toarcian sections (see discussion in Rodríguez-Tovar \& Reolid 2013). Additionally, the onset of a negative $\delta{ }^{13} \mathrm{C}$ excursion is located $2 \mathrm{~m}$ above the top of the rhythmite interval and a negative $\delta^{18} \mathrm{O}$ isotopic excursion at the rhythmite/marly interval contact and the subsequent positive isotopic excursion in the first dark marly bed are also detected. Likewise, the highest values of redoxsensitive elements $(\mathrm{Co}, \mathrm{Cr}$ ) occur in the first $2 \mathrm{~m}$ of the dark marly interval (Fig. 3).

The main T-OAE pulse was placed at the first $60 \mathrm{~cm}$ of dark marls above the top of the marl-limestone rhythmite (Figs 2, 3). From a biochronostratigraphic standpoint, the occurrence of ammonites is restricted to the marl-limestone rhythmites. The record of Dactylioceras pseudocommune, D. polymorphum and D. simplex at the top of that sequence is correlative with the polymorphum Zone according to Braga (1983) and Jiménez (1986) (see Reolid et al. 2014a for more details).

The ammonites are absent in the beginning of the dark marly interval, which include the levels containing the negative CIE. Calcareous nannoplankton has been studied in these marls. Sandoval et al. (2012) assigned this interval to the NJT5b Zone (CNZ), not evidencing the negative CIE. Subsequently, Reolid et al. (2014a) recorded the negative CIE as well as the first occurrence (FOD) of the marker Carinolithus superbus (Fig. 2) from bed 30 upwards, assigning this interval to the NJT6 Zone (CNZ). This zone usually contains the T-OAE record (Mattioli et al. 2004, 2008, 2009; Casellato \& Erba 2015), and, in other Tethyan basins, it spans the uppermost polymorphum -lower serpentinum ammonite zones.

In terms of the brachiopods, the biochronologic data from the CE section place the last occurrence datum (LOD) of Liospiriferina subquadrata within sample 22 (Fig. 2). This is the youngest record of this species worldwide, as occurrences of L. subquadrata have never been recorded from above the polymorphum-serpentinum boundary. Records of this species in nearby basins are constrained to the mirabile Subzone in Algeria (Elmi et al. 2006, Alméras et al. 2007); the mirabile-semicelatum subzones in Portugal (Comas-Rengifo et al. 2013, 2015), and the semicelatum Subzone in Pyrenees (Alméras et al. 2007). In fact, apart from this new record in the $\mathrm{CE}$ section, the presence of the representatives of the Order Spiriferinida above the polymorphum-serpentinum boundary are restricted to the La Almunia section (Iberian Range; García Joral et al. 2011) and Portugal (Comas-Rengifo et al. 2013). These authors recorded L. falloti and L.? aff. undulata, respectively, in the bed immediately overlying this boundary, together with Eleganticeras elegantulum, but never positioned above the record of the T-OAE.

On the other hand, Orthotoma aff. globulina shows a continuous record in the CE section up to sample 26, and its occasional occurrence in the 10 marks its LOD (Fig. 2). The LOD of $O$. globulina occurs in the polymorphum Zone in the Western Tethys as a whole. It is mainly recorded in Portugal and the North-African basins forming part of the koninckinid fauna (Choffat 1947, Alméras et al. 1988, Alméras \& Elmi 1993, Alméras et al. 2007) as well as in England (Ager 1990). Further records are also assigned to Orthotoma in deposits assigned even to the Pliensbachian-Toarcian transition such as Orthotoma sp. from the latest emaciatum-lowermost polymorphum zones (elisa-mirabile subzones) in the easternmost Subbetic area (Baeza-Carratalá 2013, Baeza-Carratalá et al. 2015) and Orthotoma quenstedti regarded as becoming extinct within the extinction interval of the Pliensbachian-Toarcian boundary (Harries \& Little 1999). 
Figure 7. Scatter plots of the width/length ratios (in $\mathrm{mm}$ ) on a type series of the new species Atychorhynchia falsiorigo and Koninckodonta sumuntanensis.
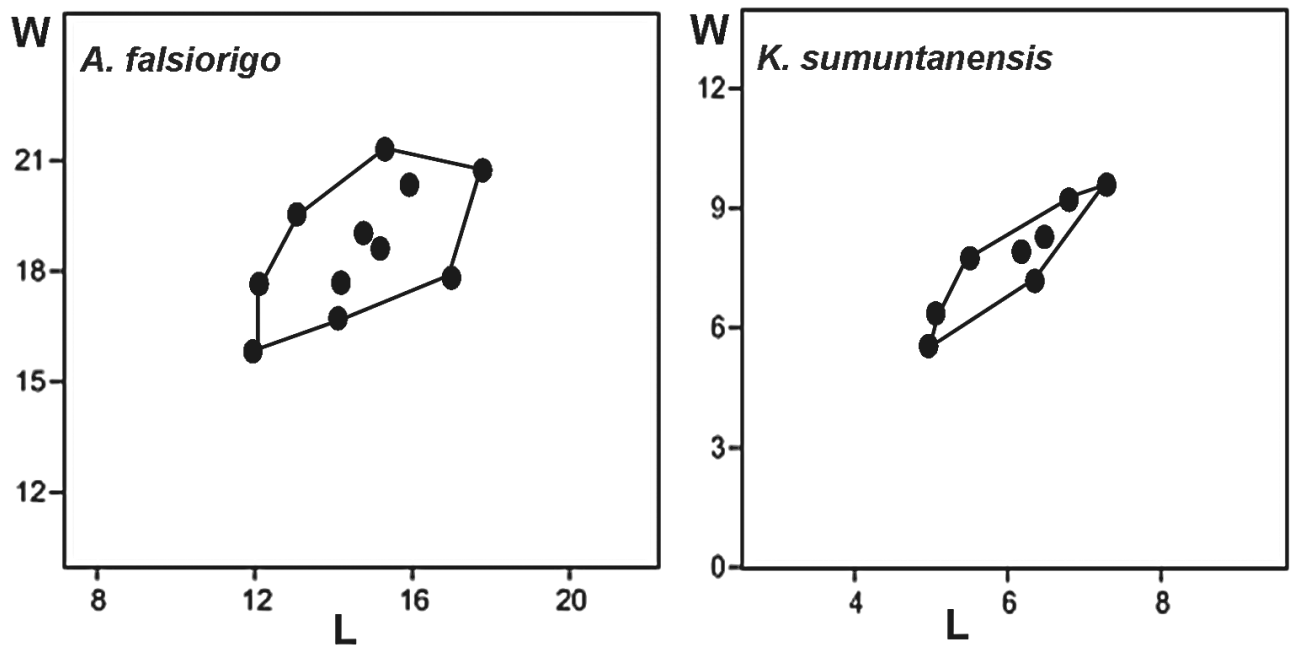

The remaining brachiopod fauna recorded does not allow biochronostratigraphic correlations as they are new taxa, probably endemic to this area. However, the record of koninckinids (beds 30-22 in CE, Fig. 2) never extends above the main extinction boundary in the Western Tethys as a whole (Vörös 2002, Baeza-Carratalá et al. 2015). The species of the classic British Leptaena beds (e.g. Davidson 1876-1878, Ager 1990) and their equivalent French Koninckella fauna (e.g. Deslongchamps 1853, Alméras et al. 1988, Alméras \& Elmi 1993, Elmi et al. 1997) become extinct at approximately the tenuicostatum-falciferum boundary, with some British records even showing that the taxon extends into the lower part of the serpentinum Zone (Vörös 2002). Their North African and Mediterranean counterparts are even recorded earlier, in the uppermost Pliensbachian-lowermost Toarcian (see Vörös 2002 and Baeza-Carratalá et al. 2015 for a revision).

Summing up, the biochronologic brachiopod data hitherto reported in the Western Tethys indicate that the CE brachiopod-bearing levels correlate with the uppermost tenuicostatum-lowermost serpentinum chronozones (semicelatum-lowermost elegantulum subchronozones). Nevertheless, the remaining fauna and geochemical proxies (Reolid et al. 2014a) suggest a younger date for this assemblage within the elegantulum Subzone and the NJT6 Zone (CNZ), but without reaching the upper part of this subchronozone, as indicated by the FOD of Soaresirhynchia bouchardi, regarded as an initial coloniser in the extinction aftermath in most of the Western Tethyan basins (e.g. García Joral \& Goy 2000, García Joral et al. 2011, Baeza Carratalá et al. 2011, Andrade et al. 2016). This is consistent with the record of an early T-OAE pulse in the CE section plausibly in the basal layers of the serpentinum Zone (Reolid et al. 2014a), bearing in mind that the expanded section in the CE area supports a significant thickness for the basal serpentinum Zone deposits.

\section{Palaeobiogeographical affinity of the CE brachiopod assemblage}

Except for Atychorhynchia falsiorigo, which can be regarded as a standard-sized form, the minute morphotypes and species comprising this assemblage suggest a relationship with those recorded in the more western North-African and Lusitanian basins. Thus, similar morphologies to Liospiriferina subquadrata and Orthotoma aff. globulina were recorded together within the Koninckella fauna in Algeria (Alméras et al. 1988, 2007; Elmi et al. 2006). These authors initially assigned the minute spiriferinid specimens recorded in Algeria and Portugal to L. villosa. Subsequently, the Algerian material was reassessed as L. subquadrata (Elmi et al. 2006, Alméras et al. 2007) including the nearly rectimarginate forms and the uniplicate ones (Alméras et al. 2007). Likewise, Comas-Rengifo et al. $(2013,2015)$ considered the minute Portuguese Liospiriferina as L. subquadrata.

Therefore it can be deduced from the cluster analysis (occurrences) constructed using the Jaccard coefficient of faunal similarity (Fig. 8, Tab. 1) and from the size comparison (Fig. 9), that the presence of minute L. subquadrata, Orthotoma aff. globulina and Koninckodonta species suggest that the assemblage from the CE section has closer links with the westernmost Tethyan areas (North-African, Portugal) than with the larger koninckinid faunas from the intra-Mediterranean bioprovince (Easternmost Subbetic, Tivoli and Umbria; Baeza-Carratalá et al. 2015). However, the brachiopod fauna from the CE section can be regarded as a separate assemblage from the Algerian and Lusitanian basins (Fig. 8, Tab. 1) due to the distinctive occurrence of new taxa such as K. sumuntanensis and Atychorhynchia falsiorigo as representative elements in the assemblage. The absence of Nannirhynchia and Pseudokingena in the CE section, genera typically recorded in Algeria and Portugal (e.g. Alméras et al. 2007; Comas-Rengifo et al. 2013, 2015), is also noteworthy. 
Table 1. Compositional table with data of the representative faunal elements in the assemblages considered in cluster analysis of the koninckinid fauna (see Fig.8).

\begin{tabular}{|c|c|c|c|}
\hline Localities & Main components of "Koninckella fauna" considered & Age & References \\
\hline British basins & $\begin{array}{l}\text { Koninckodonta davidsoni } \\
\text { Orthotoma globulina }\end{array}$ & $\begin{array}{l}\text { tenuicostatum-lowermost serpentinum zones (exaratum } \\
\text { Subzone) }\end{array}$ & $\begin{array}{l}\text { Davidson (1876), Ager (1990), } \\
\text { among others }\end{array}$ \\
\hline French basins & $\begin{array}{l}\text { Koninckella bouchardii, Koninckodonta davidsoni } \\
\text { Orthotoma globulina }\end{array}$ & tenuicostatum-falciferum zonal boundary & $\begin{array}{l}\text { Deslongchamps, (1853), } \\
\text { Alméras et al. (1991) }\end{array}$ \\
\hline La Cerradura & $\begin{array}{l}\text { Liospiriferina subquadrata, Orthotoma aff. globulina, } \\
\text { Koninckodonta sumuntanensis, Atychorhynchia falsiorigo }\end{array}$ & $\begin{array}{l}\text { uppermost polymorphum-lowermost serpentinum zones } \\
\text { (semicelatum-lower elegantulum subzones). }\end{array}$ & herein \\
\hline Portugal & Koninckella liasiana, L. subquadrata & $\begin{array}{l}\text { polymorphum Zone-earliest levisoni Zone (beds with } \\
\text { Eleganticeras elegantulum) }\end{array}$ & $\begin{array}{l}\text { Alméras \& Elmi (1993), } \\
\text { Comas-Rengifo et al. (2013, } \\
\text { 2015) }\end{array}$ \\
\hline $\begin{array}{l}\text { Morocco } \\
\text { Beni Snassen }\end{array}$ & $\begin{array}{l}\text { Koninckella liasiana, Orthotoma globulina, Liospiriferina } \\
\text { subquadrata }\end{array}$ & tenuicostatum Zone (semicelatum Subzone) & $\begin{array}{l}\text { Alméras et al. (1988), Alméras } \\
\text { \& Elmi (1993) }\end{array}$ \\
\hline NW-Algeria & Koninckella liasina, Liospiriferina subquadrata & $\begin{array}{l}\text { uppermost Pliensbachian (emaciatum Zone, elisa-solare } \\
\text { subzones) to the lowermost Toarcian (polymorphum } \\
\text { Zone, mirabile Subzone) }\end{array}$ & $\begin{array}{l}\text { Elmi et al. (2006), Alméras et } \\
\text { al. (2007) }\end{array}$ \\
\hline $\begin{array}{l}\text { Easternmost } \\
\text { Subbetic }\end{array}$ & $\begin{array}{l}\text { Koninckella bolivari, } K \text {. gibbosula, Koninckodonta } \\
\text { fornicata, } K \text {. cf. fornicata, } K \text {. davidsoni, K. waehneri, } \\
\text { Orthotoma sp. }\end{array}$ & $\begin{array}{l}\text { spinatum-polymorphum zones (elisa-mirabile } \\
\text { subzones?) }\end{array}$ & $\begin{array}{l}\text { Baeza-Carratalá (2013), } \\
\text { Baeza-Carratalá et al. } \text { (2015) }\end{array}$ \\
\hline Apennines: Tivoli & $\begin{array}{l}\text { Koninckella tiburtina }(=K . \text { bolivari), } K . \text { gibbosula, } \\
K . ? \text { choffati, Koninckodonta? auriculata, K. fornicata, } \\
K . \text { cf. waehneri, K. davidsoni, K. sicula, K. styriaca?, } \\
K \text {. cf. geyeri }\end{array}$ & earliest Toarcian & Vörös (2003) \\
\hline $\begin{array}{l}\text { Umbria: Monte } \\
\text { Serrone }\end{array}$ & $\begin{array}{l}\text { Koninckella gibbosula, } \text { K liasiana, Ortothoma apenninica; } \\
\text { Liospiriferina villosa }=\text { L. subquadrata }\end{array}$ & $\begin{array}{l}\text { polymorphum Zone: Pozza \& Bagaglia (2001), attributed } \\
\text { subsequently to the lowermost semicelatum Subzone = } \\
\text { mid-polymorphum Zone (Bilotta } \text { et al. 2010) }\end{array}$ & Pozza \& Bagaglia (2001) \\
\hline
\end{tabular}

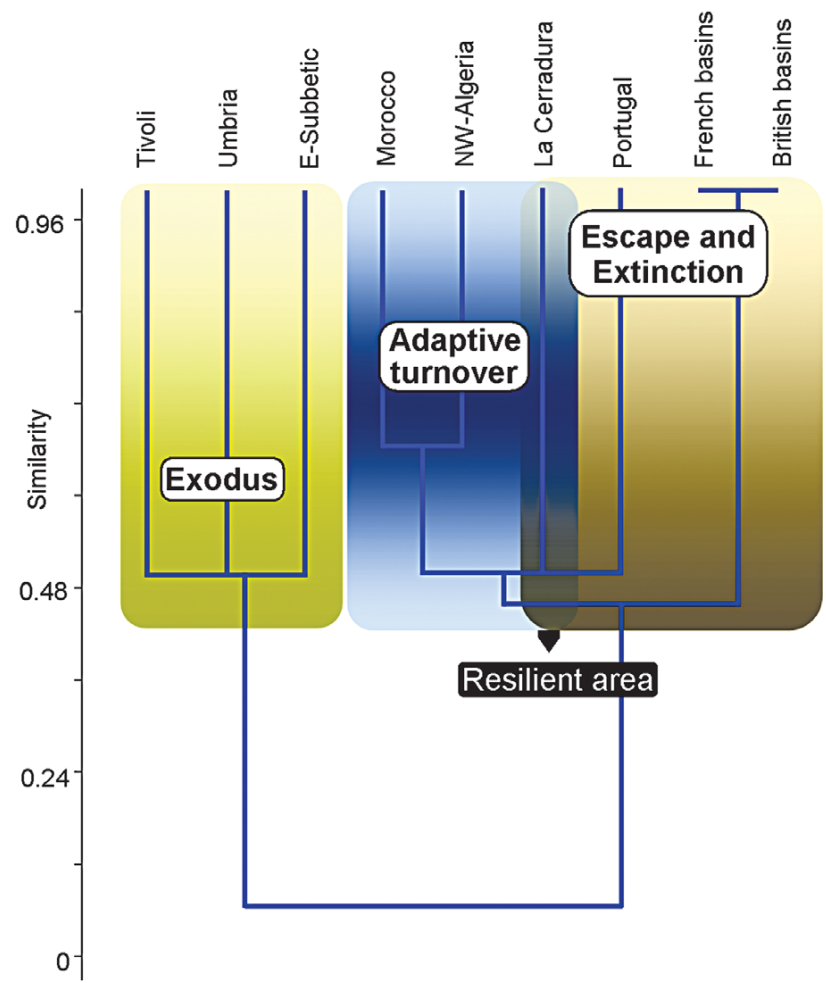

Figure 8. Cluster analysis of the koninckinid fauna in several basins using the Jaccard similarity index, including the CE section as a resilient area. This multivariate approach is interpreted in terms of the phases in koninckinid evolution, prior to their global extinction in westernmost Tethys (sensu Baeza-Carratalá et al. 2015).
Palaeobiogeographic correlations with regions from the northern margin of the Neo-Tethys Ocean were not performed because in most of the documented areas, such as the Northern Caucasus, regional factors triggered a decline of brachiopods long before the ETMEE and therefore evidence of this event is ambiguous (Ruban 2004, 2009; Ruban et al. 2015).

\section{Extinction phases of the brachiopod fauna around the ETMEE}

Several previous authors have established an extinction pattern around the ETMEE for the macrobenthic fauna which, from a broad perspective, holds for the extinction models proposed by Kauffman \& Erwin (1995) and Kauffman \& Harries (1996), although with some modifications (see Twitchett 2006 for a revision of these models).

From the wide-ranging analysis undertaken by Harries \& Little (1999) covering nektonic, planktic and benthic fauna, as regards the brachiopod fauna we can identify patterns of the (a) background conditions, (b) extinction and (c) repopulation phases. Harries \& Little (1999) detected a mass extinction with a relatively long extinction interval and an extensive survival phase into the repopulation interval (Fig. 10). Subsequent analyses specifically focused on brachiopod faunas from the westernmost Tethys Ocean (Gahr 2005, García Joral et al. 2011) resulted in new data 

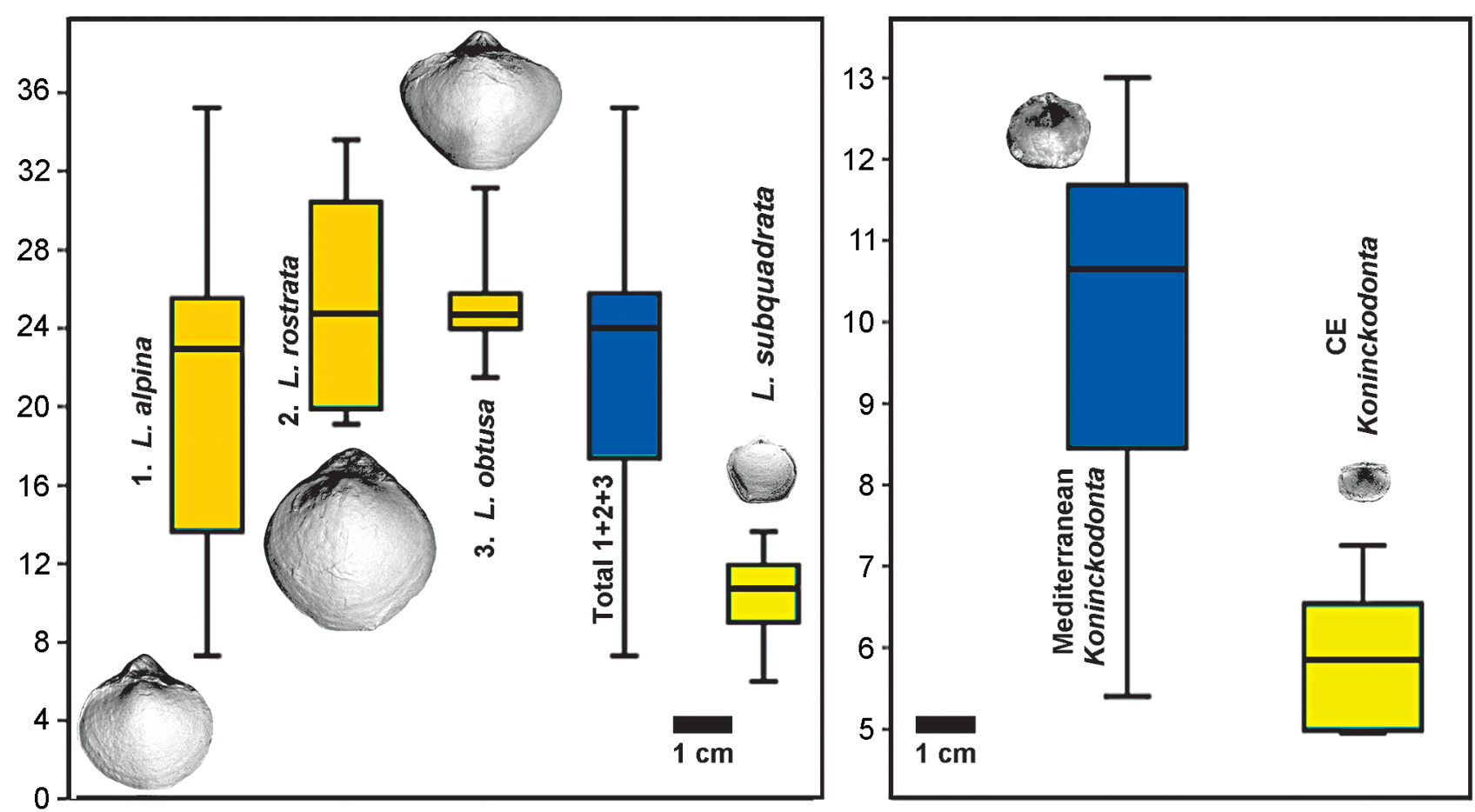

Figure 9. Boxplots showing difference in size (Length in $\mathrm{mm}$ ) between the CE populations and (A) the easternmost Subbetic spiriferinids, and (B) the global occurrences of Mediterranean koninckinids. Easternmost Subbetic dataset from Baeza-Carratalá (2008). Global Mediterranean koninckinid data from Pozza \& Bagaglia (2001), Vörös (2003), and Baeza-Carratalá (2008, 2013).

to better constrain these phases. The newly described CE brachiopod fauna documented herein offers important insight into these biotic crisis phases, as further discussed below.

In terms of the extinction interval, there are some discrepancies related to the timing of its onset and in giving support to a twofold phase in the repopulation interval after the main extinction boundary, consisting of an initial survival phase and finally a true recovery interval (Fig. 10). The present work regards these phases taking into account recent data on the evolutionary history of brachiopods around the ETMEE (e.g. Vörös 2002, 2005; García Joral et al. 2011; Baeza-Carratalá et al. 2015; Comas-Rengifo et al. 2015; Gómez et al. 2016) by adding biochronological data acquired from the westernmost Tethys areas (Braga 1983; Jiménez 1986; Sandoval et al. 2012; Comas-Rengifo et al. 2013, 2015; Reolid et al. 2014a, Baeza-Carratalá et al. 2015), and also analyzing the correlation with the isotopic curve fluctuations and palaeotemperature data in several peri-Iberian basins (Gómez \& Goy 2011, García Joral et al. 2011, Sandoval et al. 2012).

The extinction phases herein proposed (Fig. 10) closely resemble the initial pattern suggested by Harries \& Little (1999), but the extinction interval has been expanded according to the new data, with the extinction boundary placed in the basal part of the elegantulum Subzone. The definition of the extinction interval is consistent with the latter occurrences and evolution of koninckinid fauna (Baeza-Carratalá et al. 2015), which can be used as a precursor signal of a multi-phased interval with episodes of changing environmental conditions in accordance with the main isotopic excursion pulses and temperature changes. This interval is detected from the elisa-mirabile subzones, when the first evolutionary changes related to the extinction occurred, lasting up to the extinction boundary in the basal elegantulum Subzone (Baeza-Carratalá et al. 2015).

In this extinction interval, the pathway through, which koninckinid fauna passed from an initial migration to more favourable environments, to an adaptive turnover and finally to their extinction, can be followed across the Western Tethys by a species turnover, involving a general decrease in size and diversity loss. In the basins where koninckinid fauna is not recorded, this interval is characterized by the occurrence of species seemingly better adapted to warmer environments, as they are restricted to paleolatitudes around $28^{\circ}-35^{\circ} \mathrm{N}$ and this interval represents an increasing in the seawater temperature at the Iberian platform system in the order of $4-5^{\circ} \mathrm{C}$ (García Joral et al. 2011).

Thus, brachiopod data might endorse the research trend which suggests that the onset of ETMEE occurred in the late Pliensbachian-earliest Toarcian, and the extinction boundary coinciding with a thermal maximum resulting of long-term changes in environmental conditions prior to 
this event (e.g. Gómez et al. 2008, Dera et al. 2010, Suan et al. 2010, García Joral et al. 2011, Baeza-Carratalá et al. 2015).

The extinction boundary established into the lower serpentinum Zone is marked by the conspicuous impact suffered by the brachiopod fauna at a global scale. Two orders, Spiriferinida and Athyridida, which survived with low diversity since the End-Triassic Extinction (Vörös et al. 2016) became extinct (Vörös 2002, 2005; Comas-Rengifo et al. 2006; García Joral et al. 2011; Baeza-Carratalá et al. 2015) whereas the $~ 70 \%$ of the genera within the Order Rhynchonellida disappeared ( $c f$. Manceñido 2000, García Joral et al. 2011), and the Order Terebratulida underwent an important renewal (García Joral et al. 2011).

The onset of the repopulation interval into the elegantulum Zone is marked by the FOD of Soaresirhynchia bouchardi at many localities of the westernmost Tethyan basins (cf. García Joral et al. 2011, Comas-Rengifo et al. 2015). S. bouchardi fulfills the standard pattern of a bloom of opportunistic species in the sense of Levinton (1970) or Harries et al. (1996, p. 45) occupying an environment where competitors were lacking (García Joral \& Goy 2000; Gahr 2002, 2005). It is only recorded in the aftermath of the extinction, being probably the precursor of the Middle Jurassic-Cretaceous Basiliolidae. Its record marks the beginning of the repopulation interval, whose lower boundary is marked by the onset of the post-extinction radiation ( $c f$. Kauffman \& Harries 1996).

\section{Significance of the CE assemblage for the brachiopod adaptive strategies linked to the ETMEE}

Considering the brachiopod records in the $\mathrm{CE}$ section and analyzing the evolutionary trend in the westernmost Tethyan basins of the groups making up the studied assemblage, different strategies developed in the extinction phases can be deduced (Fig. 11):

\section{Pre-extinction dwarfing}

Fluctuations in the body size of several macroinvertebrates through the Pliensbachian-Toarcian extinction interval and in the aftermath of the ETMEE were studied by Morten \& Twitchett (2009) with variable results depending on the analyzed group. As a rule, size-decrease patterns linked to mass extinction events have been widely documented mainly in the aftermath of extinction boundaries through the well-known "Lilliput effect" as a post-extinction syndrome in the survival taxa (e.g. Urbanek 1993; Twitchett
2001, 2006, 2007; Harries \& Knorr 2009). However, among the significant bioevents that occurred during the brachiopod's extensive macroevolutionary history, reduction in size within an extinction interval preceding extinction boundary is, generally considerably understudied except for some noticeable data (see e.g. He et al. 2007, Zhang et al. 2016).

Previous authors (e.g. Marshall \& Corruccini 1978, Harries \& Knorr 2009) used the term "dwarfing" to designate a size pattern consisting of progressive smaller sizes within a lineage prior to, during, and in the repopulation phases of a mass extinction event. This term was then used by Wade \& Olsson (2009) for descendant populations smaller than ancestral ones preceding an extinction interval in Cenozoic planktic foraminifera, suggesting the presence of smaller size in the same lineage as an adaptive response to environmental perturbations of the water column. In terms of brachiopods, dwarfing in chonetids prior to the end-Permian mass extinction event was detected by Zhang et al. (2016).

Pre-extinction dwarfing related to ETMEE is also detected in several brachiopod stocks such as the koninckinid fauna through a spatial gradient in the westernmost Tethys (Baeza-Carratalá et al. 2015), which is related to the taxonomic composition of the assemblages. These authors identified several stages in the koninckinid fauna evolution within the extinction interval prior to the its extinction, triggering a migration from the Mediterranean mainly epioceanic areas (where the stock of large Nannirhynchia and koninckinids proliferated, e.g. N. reynesi, N. gemmellaroi, N. pilulla, K. fornicata, K. gibbosula) to the Atlantic/NW-European basins, where mostly miniaturized and paucispecific koninckinid faunas (e.g. N. pygmaea, $K$. liasiana) were widespread. The occurrences of this dwarf fauna recorded to date supported the hypothesis that this adaptive response started in the North-African basins (Baeza-Carratalá et al. 2015).

The taxonomic and morphologic composition of the brachiopod assemblage from the CE section certainly suggests affinities with the earlier North-African assemblages, which probably contained the adaptation (Figs 8, 9). Otherwise, the studied assemblage is also comparable with the younger assemblages recorded in localities from the Lusitanian Basin (Fig. 8, Tab. 1), which typify the first stages of the "escape and extinction" phase in the higher latitude Atlantic basins. In this sense, from a palaeogeographical point of view, the CE section would be located in a hemipelagic trough connected with the Hispanic Corridor (Sandoval et al. 2012, Rodríguez-Tovar \& Reolid 2013, Reolid et al. 2014a), allowing both migration through the Atlantic seaway and surviving of long-lasting species up to their total extinction within the serpentinum Zone.

Referring to the spiriferinids, the size-distribution pattern prior to their extinction is slightly more complex. 


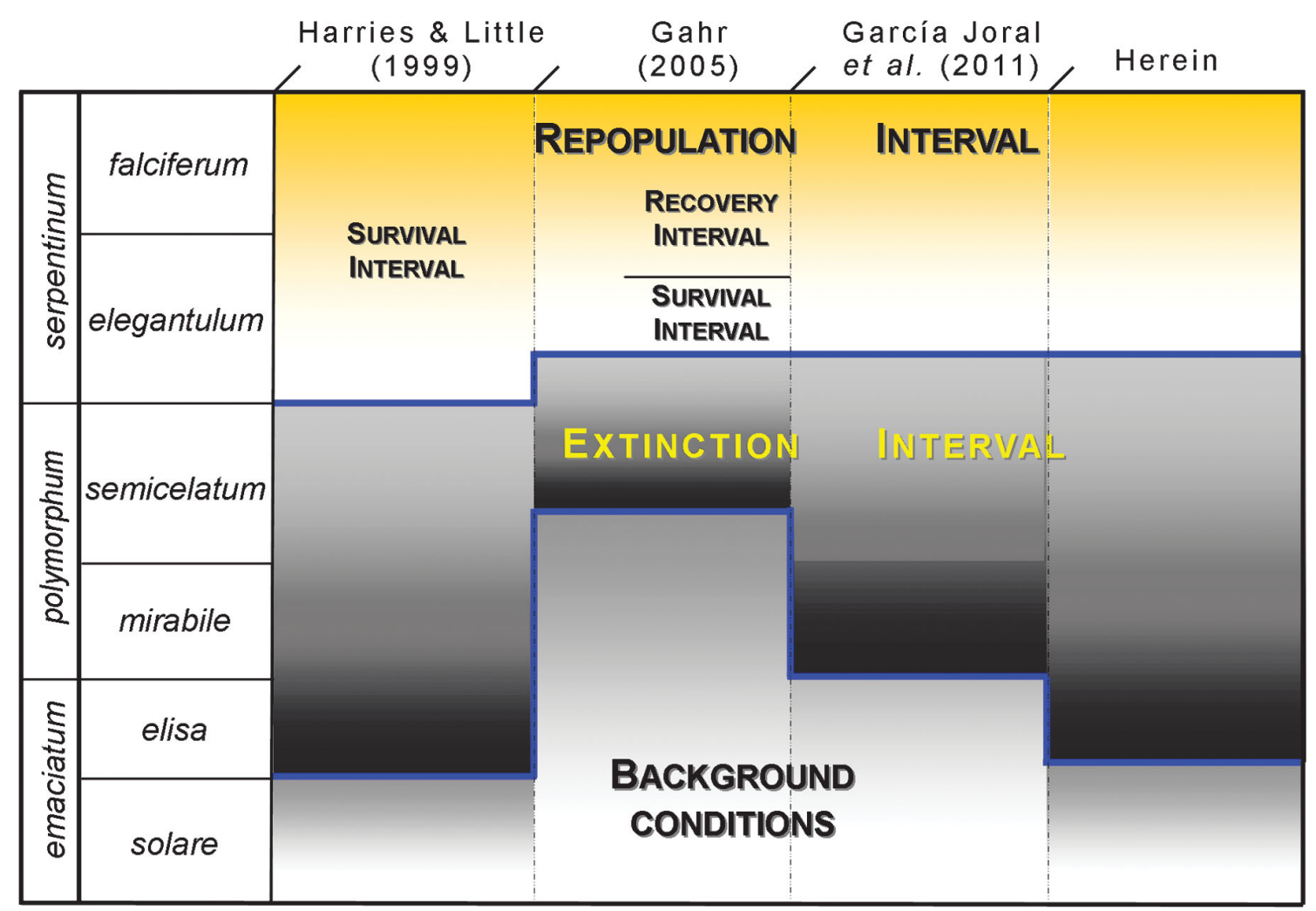

Figure 10. Pattern of the extinction phases linked to the early Toarcian Mass Extinction Event for the brachiopod fauna. The new intervals herein proposed are mainly based on data of García Joral et al. (2011) and Baeza-Carratalá et al. (2015), and also supported by several groups of macrobenthic fauna (sources in the text).

A spatial-size-decrease gradient from the Mediterranean or well-oxygenated areas to the epicontinental NW-European seas is observed also affecting the taxonomic composition of the assemblages (Fig. 9).

Minute spiriferinids such as Liospiriferina subquadrata and L. villosa are recurrently recorded in the extinction interval together with the T-OAE-precursor koninckinid fauna in NW-Algeria, Portugal, and now in the South-Iberian palaeomargin (CE section), but they are also eventually recorded with standard-size or even larger spiriferinids like L. falloti or L. rostrata in the North Gondwana Palaeomargin (Algeria), even reaching the Pyrenean Basin (Alméras \& Fauré, 2000), but never being recorded in either the background interval or in the repopulation phases.

To explain a similar uneven pattern in size change in chonetids associated with the end-Permian extinction, Zhang et al. (2016) alluded to an interspecific competition for trophic resources supply and interactions between closely related species. Dwarfing within a brachiopod lineage can be related to developmental heterochronies linked to environmental stress ( $c f$. Laurin \& García Joral 1990). As probably occurs in other taxonomic groups (Guex 2016), the progressive increase of temperature and consequently low oxygen availability in most intra-Tethyan zones triggered such adaptive responses in the brachiopod fauna (García Joral et al. 2011, Baeza-Carratalá et al. 2015).

In this context, within the extinction interval, spatial dwarfing would have been an effective short-term adaptive response to the adverse changing environmental conditions such as extreme temperatures, oxygen-depleted habitats, restricted nutrients availability, and/or turbidity. Zhang et al. (2016) inferred the reduction of food supply as a cause of the pre-extinction dwarfism in the end-Permian chonetids. In La Cerradura case, however, trophic resources were surely not the restrictive parameter as high nutrients concentration has been reported for this time interval (e.g. Jenkyns et al. 2001, Dera \& Donnadieu 2012, Rodríguez-Tovar \& Reolid 2013, Reolid et al. 2014a, Casellato \& Erba 2015), probably introduced by higher run-off and warming (weathering-induced nitrification). A quantitative study on brachiopod body size in the extinction interval will be approached by the authors in a further work to better understand this adaptive response.

On the other hand and to some extent related to this pre-extinction dwarfing, a global perspective of the koninckinid fauna in the Western Tethys as a whole can fit with a failed crisis progenitor model ( $c f$. Kauffman \& Harries 1996, Harries \& Little 1999) (Fig. 11). In the 
Pliensbachian-Toarcian transition, koninckinids mainly proliferated in the extinction interval. They successfully survived a diverse set of severe ecological perturbations, which characterize the multi-phase extinction interval, as can be deduced from several pulses and excursions displayed by biotic and isotopic signals (Vörös 2002, Baeza-Carratalá et al. 2015). They originated a premature pre-extinction radiation (Figs 8,11), but they are not recorded in the repopulation interval marked by the $S$. bouchardi-beds in the Western Tethys, not providing the successful stock for the post-extinction radiation.

\section{Resilience}

It is well-known that smooth brachiopods are representative inhabitants of deep-sea environments, especially in the Mediterranean province of the Western Tethys ( $c f$. Ager 1967; Vörös 1993, 2005). Vörös (2005) ascertained that, in the post-Palaeozoic history of brachiopods, deeper-water marine habitats might have operated as long-term reservoirs where the evolutionary lineages of smooth morphotypes survived marine crises and, under appropriate conditions, expanded to re-occupy shallow habitats. After the end-Triassic and early Toarcian extinctions, the recovery of brachiopod fauna in shallow-water marine environments was conducted by surviving smooth stocks from the deep-sea reservoir (Vörös 2005).

Several authors (e.g. Thuy et al. 2014, Andrade et al. 2016) suggested that the deep-sea fauna is not only more resilient to an extinction event than those inhabiting shallow-water, but that in situ diversification in these deeper-water habitats was probably higher than generally supposed. Hence, these areas should not be considered only refugia but as resilient environments that can produce and export high taxonomic diversity (Vörös 2005, Lindner et al. 2008, Thuy et al. 2014).

The CE section is located in a deep-water, subsiding area with expanded sedimentation and represents a pelagic marine trough situated close to the Hispanic Corridor and the passage between the Western Tethys and the Proto-Atlantic seaway (Bailey et al. 2003, Rodríguez-Tovar \& Reolid 2013, Reolid et al. 2014a). Thus, fragmentation of the South-Iberian palaeomargin in horst and graben/semigraben basins could produce such deeper sub-basins giving a potential interpretation as resilient area for the $\mathrm{CE}$ fauna.

All the brachiopods recorded in the CE section (Liospiriferina, Koninckodonta, Orthotoma, Atychorhynchia) are consistent with a very stable external morphotype consisting of a smooth ornament or very faint ribbing pattern (Fig. 5), indicative of deep-water habitats (Vörös 2005). The high evolutionary stability of this kind of deep and resilient environment enabled smooth latest Pliensbachian-early Toarcian morphotypes to withstand several perturbation peaks within the extinction interval. The assemblage of the CE section is never recorded throughout the Subbetic area. They not only survived the main ETMEE probably recorded in the lowermost serpentinum Zone in the expanded CE section, but also underwent a radiation during the extinction interval (Fig. 11) as CE brachiopods diversified their lineages developing new taxa such as Koninckodonta sumuntanensis and Atychorhynchia falsiorigo. This speciation event is consistent with the hypothesis previously mentioned of deep areas which can serve as evolutionary factories.

The FODs of these taxa are recorded within the extinction interval and did not reach the repopulation interval as defined by the FOD of $S$. bouchardi. Thus, they can be regarded as failed crisis progenitors ( $c f$. Kauffman \& Harries 1996; Harries \& Little 1999), as they could have played the role of pioneers that $S$. bouchardi achieved.

In fact, A. falsiorigo exemplifies the possible pattern followed by $S$. bouchardi, which can be regarded as an analogous morphotype. $S$. bouchardi likely originated in another similar resilient deep-water environment and, in favourable environmental conditions, colonised peri-Iberian basins (Andrade et al. 2016). Furthermore, the development of very simple and conservative morphotypes in these resilient habitats allows reaching a high diversification and provides them the potential to export taxonomic diversity, once again confirming the great dispersal potential of the deep-sea benthic biota (Vörös 2005, Thuy et al. 2014).

This scenario connects with the evolutionary factories model proposed by Andrade et al. (2016) as supplier for the late Toarcian-early Aalenian peri-Iberian brachiopod biochoremas. This evolutionary model can predispose the biogeographical distribution of Recent brachiopods already established for the Early Jurassic faunas (Vörös 2005, Zezina 2008, Thuy et al. 2014, Andrade et al. 2016).

\section{Opportunism and homoplasy}

Analyzing brachiopod trends round the ETMEE, Harries \& Little (1999) detected a clear pattern consisting of the extinction of most of the pre-boundary taxa followed by an early initial evolutionary burst in the repopulation interval. Taking into account the aforementioned pre-extinction dwarfing and resilience models, some new insights of this repopulation can be further developed by analyzing several specific groups.

New findings in the Subbetic CE section of Atychorhynchia falsiorigo and its homeomorphic external similarity with Soaresirhynchia bouchardi, regarded as the coloniser in the aftermath of the extinction marking the repopulation interval, suggests a possible crisis progenitor/survival descendant relationship. Both species are biconvex, smooth to slightly antero-marginal ribbed forms, 


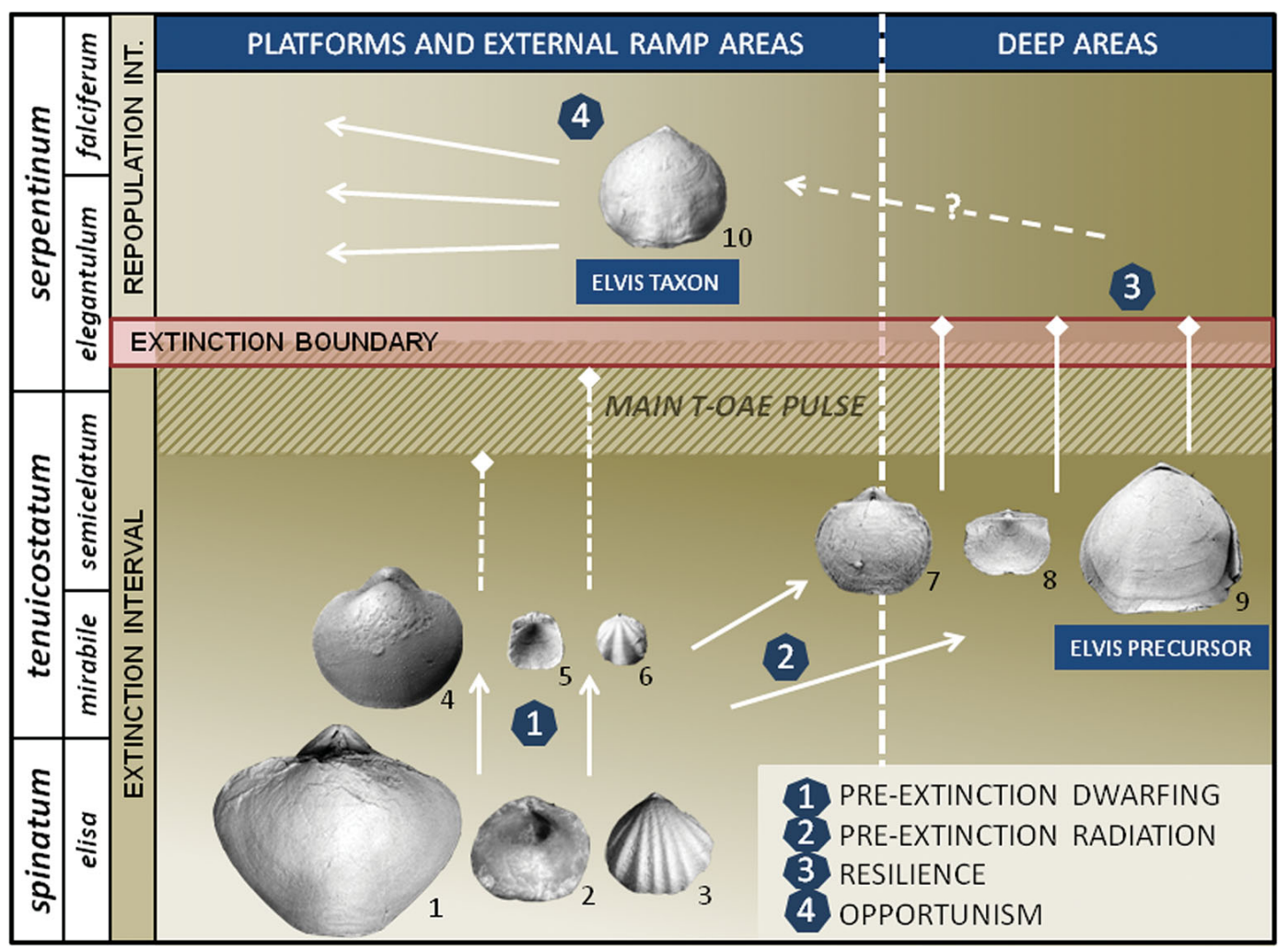

Figure 11. Summary-sketch of the evolutionary trends and adaptive strategies linked to the Early Toarcian Mass Extinction Event inferred for the brachiopod fauna in the westernmost Tethys Ocean. 1. Liospiriferina obtusa (Oppel); 2. Koninckodonta fornicata (Canavari); 3. Nannirhynchia pilulla (Schlosser in Böse and Schlosser); 4. Liospiriferina cf. falloti (Corroy); 5. Nanirhynchia pygmaea (Morris); 6. Koninckella liasiana (Bouchard in Davidson); 7. Liospiriferina subquadrata (Seguenza); 8. Koninckodonta sumuntanensis sp. nov.; 9. Atychorhynchia falsiorigo gen. et sp. nov.; 10. Soaresirhynchia bouchardi (Davidson).

uniplicate, with rounded to subpentagonal outlines, occurring above and below the mass extinction boundary.

In this situation, it would be feasible to infer a phyletic relationship between these two taxa within the evolutionary lineage Apringia (Pliensbachian)-Soaresirhynchia (early Toarcian) suggested by García Joral et al. (2011), belonging to the virtually continuous smooth uniplicate evolutionary lineage Austriellula (Triassic)-Fortunella (Early Cretaceous) pointed out by Vörös (2005), who stated that the record of this lineage suffered short gaps during the end-Triassic and early Toarcian crises and its re-appearance typifies a Lazarus effect.

Nevertheless, the accurate analysis of the internal architecture of A. falsiorigo has revealed quite different features mainly related to crural development, which enables the new taxon to be split from this lineage. Serial sections performed on the new rhynchonellids from the CE section show internal features related more to representatives within the Norellidae than those of the ApringiaSoaresirhynchia-Mondegia lineage that belong to the Basiliolidae. Although some of the accessory criteria such as the absence of a dorsal median septum and septalium are coincident in both families, the crural architecture found in the studied specimens shows a clear arcuiform development, indicative of the Early Jurassic Norellidae instead of the hamiform-subfalciform crura shown by the Basiliolidae. This situation can hence be interpreted in terms of a reasonable case of homoplasy between these taxa (Fig. 11).

Homoplasy, so-called Elvis taxa (Ervin \& Droser 1993) is a documented trend in brachiopod lineages through mass extinction events (e.g. Dulai \& Pálfy 2003) as a consequence of the relatively simple morphology of brachiopods and the adaptation of different taxa to analogous environmental conditions. In fact, external homeomorphism is a common feature among brachiopod taxa, and particularly in the smooth brachiopods, likely as a result of a convergent adaptation to deeper marine environments (Vörös 2005). Smooth forms are very simple and conservative morphotypes developed and diversified in resilient habitats such as the CE area. Thus, if A. falsiorigo from this locality represents a separate taxon from $S$. bouchardi and their Pliensbachian counterparts, $S$. bouchardi can be regarded as an Elvis taxon (Fig. 11) in correspondence with A. falsiorigo, the latter can be understood as an Elvis precursor (not in the phylogenic sense of "progenitor" but by 
the earlier occurrence of heterochronous homeomorphic forms).

The pattern of repopulation led by $S$. bouchardi, recorded in the elegantulum Subzone, occupying vacant ecospaces after the extinction boundary in both epicontinental (e.g. García Joral et al. 2011) and epioceanic areas (e.g. Baeza-Carratalá 2013), is distinctive of an opportunistic strategy (sensu Levinton 1970, Harries et al. 1996) as it shows basic external features (nearly smooth shells, subrounded outlines), morphological plasticity and simple internal architecture (Fig. 11). $S$. bouchardi-beds are also characterized by monospecific assemblages with copious specimens.

This opportunistic strategy has been perceived in the repopulation interval of several biotic crises. Thus, smooth brachiopods could also lead the Early Triassic repopulation (cf. Vörös 2005) and Basiliolidae species, probably linked to the Apringia-Fortunella lineage (like $S$. bouchardi), are also recorded leading the repopulation interval after the end-Cretaceous mass extinction, since Dulai et al. (2008) reported a monospecific assemblage composed of Basiliocostella. This genus survived in deep-water areas during the end-Cretaceous extinction interval and invaded shallow-water habitats again in the Danian (Dulai et al. 2008). The recurrent morphological similarity showed by all these taxa is indicative of an evolutionary pattern that can be generalized.

\section{Conclusions}

Lower Toarcian deposits of the peri-Iberian platform system include one of the most significant brachiopod faunas from the Western Tethys Ocean, allowing an appraisal of the epibenthic fauna in the marine ecosystems around the ETMEE.

The present analysis reviews the early Toarcian extinction phases taking into account recent data on the evolutionary history of noteworthy brachiopod groups round the ETMEE. The extinction interval has been expanded, establishing its onset likely in the elisa-mirabile subzones and the extinction boundary into the basal part of the elegantulum Subzone. The definition of the extinction interval is consistent with the later occurrences and evolution of the koninckinid fauna and the extinction boundary is marked by the conspicuous impact suffered by the brachiopod fauna at a global scale. The onset of the repopulation interval into the elegantulum Zone is marked by the FOD of Soaresirhynchia bouchardi.

The newly documented fauna recorded from La Cerradura, External Subbetic (Spain), a deep pelagic trough in the South-Iberian palaeomargin, close to the Hispanic Corridor and the passage between the Western Tethys and the Proto-Atlantic seaway, enhances compre- hensive understanding of some unique examples of adaptive strategies. Essential supplementary systematic work has to be done to identify undescribed species from the new CE site, resulting in two new taxa, Koninckodonta sumuntanensis new species and Atychorhynchia falsiorigo new genus and species.

These data support evidence of pre-extinction dwarfing and resilience in deep refugia linked to the ETMEE. An episode of speciation has been recognized in the late extinction interval which can be interpreted in terms of a pre-extinction radiation. In the same way, Atychorhynchia falsiorigo fits well with the failed crisis progenitor model, thus typifying a homoplasy case of an Elvis taxon with the pioneer opportunistic species that colonise the Western Tethys in the aftermath of the extinction, Soaresirhynchia bouchardi.

Similar strategies (pre-extinction dwarfing, resilience in deep refugia and opportunistic pioneers of similar morphology) occurred related to other mass extinction intervals such as the Permian-Triassic or the CretaceousPaleocene events, reinforcing the scheme of a possible standard pattern of the brachiopod fauna in response to such biotic crises and shedding light on the ecological effects of mass extinction events.

\section{Acknowledgements}

This research is a contribution to the IGCP-655 Toarcian Oceanic Anoxic Event: Impact on marine carbon cycle and ecosystems and was also supported by projects RYC-2009-04316 (Ramón y Cajal Program), P11-RNM-7408 (Junta de Andalucía), CGL2015-66604-R (MINECO, Government of Spain), and the Research Group VIGROB-167 (University of Alicante). Useful comments from three reviewers (A. Tomašových, M. Siblík, and D. Ruban) designated by the journal Editors are also deservedly acknowledged.

\section{References}

Aberhan, M. 2001. Bivalve palaeobiogeography and the Hispanic Corridor: time of opening and effectiveness of a proto-Atlantic seaway. Palaeogeography, Palaeoclimatology, Palaeoecology 165, 375-394.

DOI 10.1016/S0031-0182(00)00172-3

Aberhan, M. \& Fürsich, F.T. 1997. Diversity analysis of Lower Jurassic bivalves of the Andean Basin and the Pliensbachian-Toarcian mass extinction. Lethaia 29, 181-195. DOI 10.1111/j.1502-3931.1996.tb01874.x

AgER, D.V. 1959. The classification of the Mesozoic Rhynchonelloidea. Journal of Paleontology 33(2), 324-332. Ager, D.V. 1967. Some Mesozoic Brachiopods in the Tethys region, 135-151. In AdAms, C.G. \& AgER, D.V. (eds) Aspects of Tethyan Biogeography. Systematics Association Publication 7. 
Ager, D.V. 1990. British Liassic Terebratulida (Brachiopoda) Part I. Monograph of the Palaeontographical Society London 582, 143, 1-39.

AlmÉras, Y. \& Elmi, S. 1993. Palaeogeography, physiography, palaeoenvironments and brachiopod communities. Example of the Liassic brachiopods in the Western Tethys. Palaeogeography, Palaeoclimatology, Palaeoecology 100, 95-108. DOI 10.1016/0031-0182(93)90035-H

Alméras, Y. \& Fauré, P. 2000. Les Brachiopodes liasiques des Pyrénées. Paléontologie, Biostratigraphie, Paléobiogéographie et Paléoenvironnements. Strata 36, 1-395.

Alméras, Y., Elmi, S. \& Fauré, P. 2007. Les Brachiopodes Liasiques d'Algerie Occidentale. Documents des Laboratoires de Géologie Lyon 163, 3-241.

Alméras, Y., Elmi, S., Mouterde, R., Ruget, C. \& Rocha, R. 1988. Evolution Paléogéographique du Toarcien et influence sur les peuplements, 687-698. In Rocha, R.B. \& SOARES, A.F. (eds) International Symposium on Jurassic Stratigraphy. Lisboa.

Al-Suwaidi, A.H., Angelozzi, G.N., Baudin, F., Damborenea, S.E., Hesselbo, S.P., Jenkyns, H.C., Manceñido, M.O. \& RicCARDI, A.C. 2010. First record of the Early Toarcian Oceanic Anoxic Event from the Southern Hemisphere, Neuquén Basin, Argentina. Journal of the Geological Society of London 167, 633-636. DOI 10.1144/0016-76492010-025

Al-Suwaidi, A.H., Hesselbo, S.P., Damborenea, S.E., ManCeñido, M.O., Jenkyns, H.C., Riccardi, A.C., AngelozZi, G.N. \& Baudin, F. 2016. The Toarcian Oceanic Anoxic Event (Early Jurassic) in the Neuquén Basin, Argentina: A Reassessment of Age and Carbon Isotope Stratigraphy. The Journal of Geology 124, 171-193. DOI 10.1086/684831

Andrade, B., Duarte, L.V., García Joral, F., Goy, A. \& Henriques, M.H. 2016. Palaeobiogeographic patterns of the brachiopod assemblages of the Iberian Subplate during the Late Toarcian-Early Aalenian (Jurassic). Palaeogeography, Palaeoclimatology, Palaeoecology 442, 12-22.

DOI 10.1016/j.palaeo.2015.10.053

ARIAS, C. 2009. Extinction pattern of marine Ostracoda across the Pliensbachian Toarcian boundary in the Cordillera Ibérica, NE Spain: causes and consequences. Geobios 42, 1-15. DOI 10.1016/j.geobios.2008.09.004

ARIAS, C. 2013. The Early Toarcian (Early Jurassic) ostracod extinction events in the Iberian Range: The effect of temperature changes and prolonged exposure to low dissolved oxygen concentrations. Palaeogeography, Palaeoclimatology, Palaeoecology 387, 40-55. DOI 10.1016/j.palaeo.2013.07.004

Baeza-Carratalá, J.F. 2008. Patrimonio paleontológico en la colección Jiménez de Cisneros y su aplicación al estudio de los braquiópodos del Jurásico Inferior en la Cordillera Bética Oriental (provincias Alicante y Norte de Murcia). 906 pp. Ph.D. thesis, Universidad Alicante, Spain.

BAEZA-CARRATALÁ, J.F. 2013. Diversity patterns of Early Jurassic brachiopod assemblages from the westernmost Tethys (Eastern Subbetic). Palaeogeography, Palaeoclimatology, Palaeoecology 381-382, 76-91. DOI 10.1016/j.palaeo.2013.04.017

Baeza-Carratalá, J.F., García Joral, F., Giannetti, A. \&
Tent-Manclús, J.E. 2015. Evolution of the last koninckinids (Athyridida, Koninckinidae), a precursor signal of the Early Toarcian mass extinction event in the Western Tethys. Palaeogeography, Palaeoclimatology, Palaeoecology 429, 41-56. DOI 10.1016/j.palaeo.2015.04.004

Baeza-Carratalá, J.F., García Joral, F. \& Tent-Manclús, J.E. 2011. Biostratigraphy and palaeobiogeographic affinities of the Jurassic brachiopod assemblages from Sierra Espuña (Maláguide Complex, Internal Betic Zones, Spain). Journal of Iberian Geology 37(2), 137-151. DOI 10.5209/rev_JIGE.2011.v37.n2.3

Bailey, T.R., Rosenthal, Y., McArthur, J.M., VAN DE Schootbrugge, B. \& Thirlwall, M.F. 2003. Paleoceanographic changes of the Late Pliensbachian-Early Toarcian interval: a possible link to the genesis of an Oceanic Anoxic Event. Earth and Planetary Science Letters 212, 307-320. DOI 10.1016/S0012-821X(03)00278-4

Bassoullet, J.P., Elmi, S., Poisson, A., Ricou, L.E., Cecca, F., Bellión, Y., Giraud, R. \& Baudin, F., 1993. Middle Toarcian (184-182 Ma.). In Decourt, J., Ricou, L. E. \& VRielynck, B. (eds) Atlas Tethys Palaeoenviromental Maps. Beicip-Franlab, Rueil-Malmaison.

BitTNER, A. 1893. Neue Koninckiniden des alpine Lias. Jahrbuch der kaiserlich-königlichen geologischen Reinchsalstat 43(1), 133-144.

Boucot, A.J., Johnson, J.G. \& Staton, R.D. 1964. On some atrypoid, retzioid, and athyridoid Brachiopoda. Journal of $\mathrm{Pa}$ leontology 38, 805-822.

Braga, J.C. 1983. Ammonites del Domerense de la zona Subbética (Cordilleras Béticas, S. de España). 410 pp. Ph.D. thesis, Universidad Granada, Spain.

Braga, J.C., Comas, M.C., Delgado, F., García-Hernández, M., Jiménez, A.P., Linares, A., Rivas, P. \& Vera, J.A. 1981. The Liassic rosso ammonitico facies in the Subbetic Zone (Spain). Genetic consideration, 61-76. In FARINACCI, A. \& Elmi, S. (eds) Rosso Ammonitico Symposium Proceedings. Tecnoscienza, Rome.

Bucefalo Palliani, R., Mattioli, E. \& Riding, J.B. 2002. The response of marine phytoplankton and sedimentary organic matter to the Early Toarcian (Lower Jurassic) oceanic anoxic event in northern England. Marine Micropaleontology 46, 223-245. DOI 10.1016/S0377-8398(02)00064-6

Caniço, A., Duarte, L.V., Rocha, F., Reolid, M. \& Terroso, D. 2015. Palaeoenvironmental meaning of clay minerals assemblages across the late Pliensbachian-Early Toarcian (Early Jurassic) of Iberian Peninsula: Lusitanian, Algarve and Subbetic basins. Abstracts Euroclay 2015, p. 115.

Cariou, E. \& HantzPergue, P. 1997. Groupe Français d'Études du Jurassique, biostratigraphie du Jurassique ouest-européen et méditerranéen. Zonations parallèles et distribution des invertébrés et microfossiles. Bulletin des Centres de Recherches Exploration-Production d'Elf-Aquitaine 17, $1-400$.

Caruthers, A.H., Grocke, D.R. \& SMith, P.L. 2011. The significance of an Early Jurassic (Toarcian) carbon-isotope excursion in Haida Gwaii (Quenn Charlotte Islands), British Co- 
lumbia, Canada. Earth and Planetary Science Letters 307, 19-26. DOI 10.1016/j.eps1.2011.04.013

Caruthers, A.H., Smith, P.L. \& GröCKe, D.R. 2013. The Pliensbachian-Toarcian (Early Jurassic) extinction, a global multi-phased event. Palaeogeography, Palaeoclimatology, Palaeoecology 386, 104-118. DOI 10.1016/j.palaeo.2013.05.010

Casellato, C.E. \& ERBA, E. 2015. Calcareous nannofossil biostratigraphy and paleoceanography or the Toarcian Oceanic Anoxic Event at Colle di Sogno (Southern Alps, Northern Italy). Rivista Italiana di Paleontologia e Stratigrafia 121, 297-327.

Cecca, F. \& Macchioni, F. 2004. The two Early Toarcian (Early Jurassic) extinction events in ammonoids. Lethaia 37, 35-56. DOI 10.1080/00241160310008257

Choffat, P. 1947. Description de la faune jurassique du Portugal. Brachiopodes. Mémoires du Service Géologique du Portugal, $1-46$.

Comas-Rengifo, M.J., Duarte, L.V., Félix, F.F., García Joral, F., Goy, A. \& Rocha, R.B. 2015. Latest Pliensbachian-Early Toarcian brachiopod assemblages from the Peniche section (Portugal) and their correlation. Episodes 38, 2-8.

Comas-Rengifo, M.J., Duarte, L.V., García Joral, F. \& Goy, A. 2013. Los braquiópodos del Toarciense Inferior (Jurásico) en el área de Rabaçal-Condeixa (Portugal): distribución estratigráfica y paleobiogeografía. Comunicações Geológicas 100(1), 37-42.

Comas-Rengifo, M.J., García Joral, F. \& Goy, A. 2006. Spiriferinida (Brachiopoda) del Jurásico Inferior del NE y N de España: distribución y extinción durante el evento anóxico oceánico del Toarciense Inferior. Boletín de la Real Sociedad Española de Historia Natural, Sección Geológica 101, 147-157.

DAvidson, T. 1853. British Fossil Brachiopoda, vol. I. Introduction. 136 pp., 9 pl. Palaeontographical Society Monograph, London.

Davidson, T. 1876-1878. A monograph of the British fossil Brachiopoda 4 (2), Triassic-Jurassic Supplement. Palaeontographical Society, London, 73-242.

Dera, G. \& Donnadieu, Y. 2012. Modeling evidences for global warming, Arctic seawater freshening, and sluggish oceanic circulation during the Early Toarcian anoxic event. Paleoceanography 27, PA2211. DOI 10.1029/2012PA002283

Dera, G., Neige, P., Dommergues, J.L., Fara, E., Laffont, R. \& Pellenard, P. 2010. High resolution dynamics of Early Jurassic marine extinctions: the case of Pliensbachian-Toarcian ammonites (Cephalopoda). Journal of the Geological Society of London 167, 21-33.

DOI 10.1144/0016-76492009-068

DeslongChamps, E.E. 1853. Mémoire sur les genres Lœptaena et Thecidea des terrains Jurassiques du Calvados. Mémoires de la Société Linnéenne de Normandie 9, 213-250.

Dulai, A. \& PÁlfy, J. 2003. The terebratulid brachiopod Lobothyris? subgregaria as an Early Jurassic Elvis species from Hungary. 3rd Workshop of the IGCP Project 458: "Tri-
assic/Jurassic Boundary Changes”, Stará Lesná, Slovakia, 45-46.

Dulai, A., Bitner, M.A. \& Müller, P.Á.L. 2008. A monospecific assemblage of a new rhynchonellide brachiopod from the Paleocene of Austria. Fossils and Strata 54, 193-201.

Elmi, S., Marok, A., Sebane, A. \& Alméras, Y. 2006. Importance of the Mellala section (Traras Mountains, NW Algeria) for the correlations of the Pliensbachian/Toarcian boundary. Volumina Jurassica 4, 158-160.

Elmi, S., Roulleau, L., Gabilly, J. \& Mouterde, R. 1997. Toarcien. Biostratigraphie du Jurassique ouest-européen et méditerranéen: zonations parallèles et distribution des invertébrés et microfossiles. In Cariou, E. \& Hantzpergue, P. (eds) Bulletin des Centres de Recherches Exploration-Production d'Elf-Aquitaine 17, 25-36.

Erwin, D. \& Droser, M. 1993. Elvis Taxa. Palaios 8, 623-624. DOI $10.2307 / 3515039$

GAHr, M.E. 2002. Palökologie des Makrobenthos aus dem Unter-Toarc SW-Europas. Beringeria 31, 3-204.

GAHR, M. 2005. Response of Lower Toarcian (Lower Jurassic) macrobenthos of the Iberian Peninsula to sea level changes and mass extinction. Journal of Iberian Geology 31, $197-215$.

García Joral, F. \& Goy, A. 2000. Stratigraphic distribution of Toarcian brachiopods from the Iberian Range and its relation to depositional sequences. Georesearch Forum 6, 381-386.

García Joral, F., Gómez, J.J. \& Goy, A. 2011. Mass extinction and recovery of the Early Toarcian (Early Jurassic) brachiopods linked to climate change in northern and central Spain. Palaeogeography, Palaeoclimatology, Palaeoecology 302, 367-380. DOI 10.1016/j.palaeo.2011.01.023

García-Hernández, M., López-Garrido, A.C., MartínAlgarra, A., Molina, J.M., Ruiz-Ortiz, P.A. \& Vera, J.A. 1989. Las discontinuidades mayores del Jurásico de las Zonas Externas de las Cordilleras Béticas: Análisis e interpretación de los ciclos sedimentarios. Cuadernos de Geología Ibérica $13,35-52$.

García-Hernández, M., Lupiani, E. \& Vera, J.A. 1987. La sedimentación liásica den el sector central del Subbético medio: registro de la evolución de un rift intracontinental. Acta Geológica Hispánica 21-22, 329-337.

GómEZ, J.J. \& Goy, A. 2011. Warming-driven mass extinction in the Early Toarcian (Early Jurassic) of northern and central Spain. Correlation with other time-equivalent European sections. Palaeogeography, Palaeoclimatology, Palaeoecology 306, 176-195. DOI 10.1016/j.palaeo.2011.04.018

Gómez, J.J., Comas-Rengifo, M.J. \& Goy, A. 2016. Palaeoclimatic oscillations in the Pliensbachian (Early Jurassic) of the Asturian Basin (Northern Spain). Climate of the Past 12, 1199-1214. DOI 10.5194/cp-12-1199-2016

Gómez, J.J., Goy, A. \& CANALES, M.L. 2008. Seawater temperature and carbon isotope variations in belemnites linked to mass extinction during the Toarcian (Early Jurassic) in Central and Northern Spain. Comparison with other European sections. Palaeogeography, Palaeoclimatology, Palaeoecology 258, 28-58. DOI 10.1016/j.palaeo.2007.11.005 
GuEX, J. 2016. Retrograde evolution during major extinction crises. 77 pp. Springer, Cham. DOI 10.1007/978-3-319-27917-6

Hallam, A. 1986. The Pliensbachian and Tithonian extinction events. Nature 319, 765-768. DOI 10.1038/319765a0

Hallam, A. 1987. Radiations and extinctions in relation to environmental change in the marine Lower Jurassic of northwest Europe. Paleobiology 13, 152-168. DOI 10.1017/S0094837300008708

Hallam, A. 1990. The end-Triassic mass extinction event. Geological Society of America Special Paper 247, 577-583. DOI 10.1130/spe247-p577

Hallam, A. 1996. Recovery of the marine fauna in Europe after the end-Triassic and early Toarcian mass extinctions, 231-236. In HART, M.B. (ed.) Biotic Recovery from Mass Extinction Events. Geological Society of London, Special Publications 102.

Hammer, O., Harper, D.A.T. \& Ryan, P.D. 2001. Paleontological statistics software package for education and data analysis: Palaeontologia Electronica 4, 1-9.

HARPER, D.A.T. 1993. Suborders Athyrididina, Retziidina, Dayiidina, Koninckinidina, Thecideidina, 447-450. In Benton, M.J. (ed.) The fossil record 2. Brachiopoda. Chapman \& Hall, London.

Harries, P.J. \& Knorr, P.O. 2009. What does the 'Lilliput Effect' mean? Palaeogeography, Palaeoclimatology, Palaeoecology 284, 4-10. DOI 10.1016/j.palaeo.2009.08.021

Harries, P.J. \& Little, C.T.S. 1999. The Early Toarcian (Early Jurassic) and the Cenomanian-Turonian (Late Cretaceous) mass extinctions: similarities and contrasts. Palaeogeography, Palaeoclimatology, Palaeoecology 154, 39-66.

Harries, P.J., KaufFMan, E.G. \& Hansen, T.A. 1996. Models for Biotic Survival Following Mass Extinction. Biotic recovery from mass extinction events, 41-60. In HART, M.B. (ed.) Geological Society of London, Special Publication 102. DOI 10.1144/gsl.sp.1996.001.01.03

He, W., Shi, G.R., Feng, Q., CAmpi, M.J., Gu, S., Bu, J., Peng, Y. \& Meng, Y. 2007. Brachiopod miniaturization and its possible causes during the Permian-Triassic crisis in deep water environments, South China. Palaeogeography, Palaeoclimatology, Palaeoecology 252, 132-144.

DOI 10.1016/j.palaeo.2006.11.040

Hermoso, M., Minoletti, F., Le Callonnec, L., Jenkyns, H.C., Hesselbo, S.P., Rickaby, R.E.M., Renard, M., Rafaelis, M. DE \& EMmANUEL, L. 2009. Global and local forcing of Early Toarcian seawater chemistry: A comparative study of different paleoceanographic settings (Paris and Lusitanian basins). Paleoceanography 24, PA4208.

DOI 10.1029/2009PA001764

Hesselbo, S.P., Jenkyns, H.C., Duarte, L.V. \& Oliveira, L.C.V. 2007. Carbon-isotope record of the Early Jurassic (Toarcian) oceanic anoxic event from fossil wood and marine carbonate (Lusitanian Basin, Portugal). Earth and Planetary Science Letters 253, 455-470. DOI 10.1016/j.eps1.2006.11.009

JABLONSKI, D. 2002. Survival without recovery after mass extinctions. Proceedings of the National Academy of Sciences U.S.A. 99, 8139-8144. DOI 10.1073/pnas.102163299
JENKyns, H.C. 1988. The Early Toarcian (Jurassic) anoxic event: stratigraphy, sedimentary and geochemical evidence. American Journal of Science 288, 101-151.

DOI 10.2475/ajs.288.2.101

Jenkyns, H.C. \& Clayton, C.J. 1997. Lower Jurassic epicontinental carbonates andmudstones from England and Wales: chemostratigraphic signals and the Early Toarcian anoxic event. Sedimentology 44, 687-706. DOI 10.1046/j.1365-3091.1997.d01-43.x

Jenkyns, H.C., Gröcke, D.R. \& Hesselbo, S.P. 2001. Nitrogen isotope evidence for water mass denitrification during the early Toarcian (Jurassic) oceanic anoxic event. Paleoceanography 16, 593-603. DOI 10.1029/2000PA000558

JIMÉNEZ, A.P., 1986. Estudio paleontológico de los ammonites del Toarciense inferior y medio de las Cordilleras Béticas (Dactylioceratidae e Hildoceratidae). 252 pp. Ph.D. thesis, Universidad de Granada, Spain.

JiMÉNEZ, A.P. \& RivAs, P. 1979. El Toarciense en la zona Subbética. Cuadernos de Geología de la Universidad de Granada 10, 397-411.

Jiménez, A.P., Jiménez de Cisneros, C., Rivas, P. \& Vera, J.A. 1996. The Early Toarcian Anoxic Event in the Westernmost Tethys (Subbetic): Paleogeographic and Paleobiogeographic significance. Journal of Geology 104, 399-416.

DOI 10.1086/629836

KAESLER, R.L. \& SELDEN, P.A. (eds) 1997-2007. Treatise on Invertebrate Paleontology. Part H, Brachiopoda, Revised, Vols 1-6. Geological Society of America \& Paleontological Institute, Boulder, Colorado \& Lawrence.

KaUfFMAN, E.G., ERwin, D.H. 1995. Surviving mass extinctions. Geotimes 14, 14-17.

Kauffman, E.G. \& Harries, P.J. 1996. The importance of crisis progenitors in recovery from mass extinction, 15-39. In HART, M.B. (ed.) Biotic Recovery from Mass Extinction Events, Geological Society of London, Special Publications 102.

Kunn, O. 1949. Lehrbuch der Paläozoologie. 326 pp. E. Schweizerbart'sche Verlagsbuchhandlung, Stuttgart.

LAthuilière, B. \& Marchal, D. 2009. Extinction, survival and recovery of corals from the Triassic to Middle Jurassic time. Terra Nova 21, 57-66.

DOI 10.1111/j.1365-3121.2008.00856.x

LAURIN, B. \& GARCía JoRAL, F. 1990. Miniaturization and heterochrony in Homoeorhynchia meridionalis and H. cynocephala (Brachiopoda, Rhynchonelidae) from the Jurassic of the Iberian Range, Spain. Paleobiology 16, 62-76. DOI $10.1017 / \mathrm{S} 0094837300009738$

LEVINTON, J.S. 1970. The paleoecological significance of opportunistic species. Lethaia 3, 69-78. DOI 10.1111/j.1502-3931.1970.tb01264.x

Lindner, A., Cairns, S.D. \& Cunningham, C.W. 2008. From offshore to onshore: multiple origins of shallow water corals from deep-sea ancestors. PLoS One 3, e2429. DOI 10.1371/journal.pone.0002429

LitTLE, C.T.S. 1996. The Pliensbachian-Toarcian (Lower Jurassic) extinction event. Special Paper of the Geological Society of America 307, 505-512. DOI 10.1130/0-8137-2307-8.505 
LitTle, C.T.S. \& Benton, M.J. 1995. Early Jurassic mass extinction: A global long-term event. Geology 23, 495-498. DOI 10.1130/0091-7613(1995)023<0495:EJMEAG>2.3.CO;2

Littler, K., Hesselbo, S.P. \& Jenkyns, H.C. 2010. A carbon-isotope perturbation at the Pliensbachian-Toarcian boundary: evidence from the Lias Group, NE England. Geological Magazine 147, 181-192. DOI 10.1017/S0016756809990458

Macchioni, F. \& CeCCA, F. 2002. Biodiversity and biogeography of middle-late liassic ammonoids: implications for the Early Toarcian mass extinction. Geobios 35, 165-175. DOI 10.1016/S0016-6995(02)00057-8

ManCEÑIDO, M.O. 2000. A systematic summary of the stratigraphic distribution of Jurassic rhynchonellide genera (brachiopoda). Advances in Jurassic Research 2000, 387-396. In Hall, R.L., SMith, P.L. (eds) Proceedings of the Fifth International Symposium on the Jurassic System, GeoResearch Forum 6.

ManceÑIdo, M.O. 2002. Paleobiogeography of Mesozoic brachiopod faunas from Andean-Patagonian areas in a global context. Geobios 35, 176-192.

DOI 10.1016/S0016-6995(02)00058-X

Marshall, L.G. \& CorruccinI, R.S. 1978. Variability, evolutionary rates, and allometry in dwarfing lineages. Paleobiology 4, 101-118.

Mattioli, E. \& Erba, E. 1999. Synthesis of calcareous nannofossil events in the Tethyan Lower and Middle Jurassic. Rivista Italiana di Paleontologia e Stratigrafia 105, 343-376.

Mattioli, E., Pittet, B., Bucefalo Palliani, R., Röhl, H.J., SCHMID-RÖHL, A. \& Morettini, E. 2004. Phytoplankton evidence for the timing and correlation of palaeoceanographical changes during the Early Toarcian oceanic anoxic event (Early Jurassic). Journal of the Geological Society of London 161, 685-693. DOI 10.1144/0016-764903-074

Mattioli, E., Pittet, B., Petitpierre, L. \& Mailliot, S. 2009. Dramatic decrease of the pelagic carbonate production by nannoplankton across the Early Toarcian Anoxic Event (TOAE). Global and Planetary Change 65, 134-145. DOI 10.1016/j.gloplacha.2008.10.018

Mattioli, E., Pittet, B., Suan, G. \& Mailliot, S. 2008. Calcareous nannoplankton across the Early Toarcian Anoxic Event: implications for paleoceanography within the western Tethys. Paleoceanography 23, PA3208. DOI 10.1029/2007PA001435

Mattioli, E., PlancQ, J., Boussaha, M., Duarte, L.V. \& Pittet, B. 2013. Calcareous nannofossil biostratigraphy: new data from the Lower Jurassic of the Lusitanian Basin. Comunicaçoes Geológicas 100, Especial I, 69-76.

McArthur, J.M., Algeo, T.J., van de Schootbrugge, B., Li, Q. \& Howarth, R.J. 2008. Basinal restriction, black shales, Re-Os dating, and the Early Toarcian (Jurassic) oceanic anoxic event. Paleoceanography 23, PA4217. DOI 10.1029/2008PA001607

McArthur, J.M., Donovan, D.T., Thirvall, M.F., Fouke, B.W. \& Mattey, D. 2000. Strontium isotope of the Early Toarcian (Jurassic) oceanic anoxic event, the duration of ammonite biozones and belemnite palaeotemperatures. Earth and Plane- tary Science Letters 179, 269-285.

DOI 10.1016/S0012-821X(00)00111-4

Morten, S.D. \& TwitchetT, R.J. 2009. Fluctuations in the body size of marine invertebrates through the Pliensbachian-Toarcian extinction event. Palaeogeography, Palaeoclimatology, Palaeoecology 284, 29-38. DOI 10.1016/j.palaeo.2009.08.023

Mouterde, R., Busnardo, R. \& Linares, A. 1971. Le Domérien dans le Subbetique Central (Andalusie). Données préliminaires. Cuadernos de Geología Ibérica 2, 237-254.

Nikitenko, B.L. \& Mickey, M.B. 2004. Foraminifera and ostracodes across the Pliensbachian-Toarcian boundary in the Arctic Realm. Geological Society of London, Special Publication 230, 137-173. DOI 10.1144/GSL.SP.2004.230.01.08

PozZA, G.C. \& BAgaglia, A. 2001. A Koninckella fauna recorded from the s.s. type-locality of the Marne di M. Serrone Formation (Umbria, Central Italy, Northern Apennine). 1 Part. Revue de Paléobiologie 20, 19-29.

Reolid, M., Chakiri, S. \& BejJaJi, Z. 2013a. Adaptative strategies of the Toarcian benthic foraminiferal assemblages from the Middle Atlas (Morocco): palaeoecological implications. Journal of African Earth Sciences 84, 1-12. DOI 10.1016/j.jafrearsci.2013.03.008

Reolid, M., Nieto, L.M. \& SÁnchez-Almazo, I.M. 2013 b. Caracterización geoquímica de facies pobremente oxigenadas en el Toarciense inferior (Jurásico inferior) del Subbético Externo. Revista de la Sociedad Geológica de España 26, 69-84.

Reolid, M., Marok, A. \& Sebane, A. 2014b. Foraminiferal assemblages and geochemistry for interpreting the incidence of Early Toarcian environmental changes in North Gondwana palaeomargin (Traras Mountains, Algeria). Journal of African Earth Sciences 95, 105-122.

DOI 10.1016/j.jafrearsci.2014.03.004

Reolid, M., Mattioli, E., Nieto, L.M. \& Rodríguez-Tovar, F.J. 2014a. The Early Toarcian Ocanic Anoxic Event in the External Subbetic (Southiberian Palaeomargin, Westernmost Tethys): geochemistry, nannofossils and ichnology. Palaeogeography, Palaeoclimatology, Palaeoecology 411, 79-94. DOI 10.1016/j.palaeo.2014.06.023

Reolid, M., Rivas, P. \& Rodríguez-Tovar, F.J. 2015. Toarcian ammonitico rosso facies from the South Iberian Paleomargin (Betic Cordillera, southern Spain): paleoenvironmental reconstruction. Facies 61, 22. DOI 10.1007/s10347-015-0447-3

Rita, P., Reolid, M. \& Duarte, L.V. 2016. The incidence of the Late Pliensbachian -Early Toarcian biotic crisis from ecostratigraphy of benthic foraminiferal assemblages: new insights from the Peniche reference section, Portugal. Palaeogeography, Palaeoclimatology, Palaeoecology 454, 267-281. DOI 10.1016/j.palaeo.2016.04.039

RodríguEZ-Tovar, F.J. \& REOLID, M. 2013. Environmental conditions during the Toarcian Oceanic Anoxic Event (T-OAE) in the westernmost Tethys: influence of the regional context on a global phenomenon. Bulletin of Geosciences 88, 697-712. DOI 10.3140/bull.geosci.1397

Rodríguez-Tovar, F.J. \& UChman, A. 2010. Ichnofabric evi- 
dence for the lack of bottom anoxia during the Lower Toarcian Oceanic Anoxic Event (T-OAE) in the Fuente de la Vidriera section, Betic Cordillera, Spain. Palaios 25, 576-587. DOI 10.2110/palo.2009.p09-153r

Roldán, F.J., Lupiani, E., Villalobos, M. \& Jerez-Mir, L. 1991. Mapa y Memoria explicativa de la Hoja 947, Jaén. MAGNA. Instituto Geológico y Minero de España.

Ruban, D.A. 2004. Diversity dynamics of Early-Middle Jurassic brachiopods of Caucasus, and the Pliensbachian-Toarcian mass extinction. Acta Palaeontologica Polonica 49, 275-282.

RubAn, D.A. 2009. Brachiopod decline preceded the Early Toarcian mass extinction in the Northern Caucasus (northern Neo-Tethys Ocean): A palaeogeographical context. Revue de Paléobiologie 28, 85-92.

Ruban, D.A., Radulovic, B.V., \& Radulovic, V.J. 2015. Diversity dynamics of Early and Middle Jurassic brachiopods in the Getic and Danubian tectonic units of eastern Serbia. Palaeogeography, Palaeoclimatology, Palaeoecology 425, 97-108. DOI 10.1016/j.palaeo.2015.02.013

Sandoval, J., Bill, M., Aguado, R., O’Dogherty, L., Rivas, P., Morard, A. \& Guex, J. 2012. The Toarcian in the Subbetic basin (southern Spain): Bioevents (ammonite and calcareous nannofossils) and carbon-isotope stratigraphy. Palaeogeography, Palaeoclimatology, Palaeoecology 342-343, 40-63. DOI 10.1016/j.palaeo.2012.04.028

SAvage, N.M., Manceñido, M.O. \& Owen, E.F. 2002. Order Rhynchonellida. In Williams, A., Brunton, C.H.C., CARLSON, S.J.et al. (eds) Treatise on Invertebrate Palaeontology. Part H, Brachiopoda (Revised), Volume 4, Rhynchonelliformea (part). 807 pp. Geological Society of America and University of Kansas, Boulder, Colorado and Lawrence.

Suan, G., Mattioli, E., Pittet, B., Lécuyer, C., SuchérasMarx, B., Duarte, L.V., Philippe, M., Reggiani, L. \& Martineau, F. 2010. Secular environmental precursors to Early Toarcian (Jurassic) extreme climate changes. Earth and Planetary Science Letters 290, 448-458. DOI 10.1016/j.epsl.2009.12.047

Suan, G., Pittet, B., Bour, I., Mattioli, E., Duarte, L.V. \& Mailliot, S. 2008. Duration of the Early Toarcian carbon isotope excursion deduced from spectral analysis: consequence for its possible causes. Earth and Planetary Science Letters 267, 666-679. DOI 10.1016/j.epsl.2007.12.017

Thuy, B., Kiel, S., Dulai, A., Gale, A.S., Kroh, A., Lord, A.R., Numberger-Thuy, L.D., STÖHR, S. \& WisshaK, M. 2014. First glimpse into Lower Jurassic deep-sea biodiversity: in situ diversification and resilience against extinction. Proceedings of the Royal Society B 281, 20132624.

DOI 10.1098/rspb.2013.2624

TOMAŠOvÝCH, A. \& SiBLíK, M. 2007. Evaluating compositional turnover of brachiopod communities during the end-Triassic mass extinction (Northern Calcareous Alps): Removal of dominant groups, recovery and community reassembly. Palaeogeography, Palaeoclimatology, Palaeoecology, 244, 170-200. DOI 10.1016/j.palaeo.2006.06.028
Twitchett, R.J. 2001. Incompleteness of the Permian-Triassic fossil record: a consequence of productivity decline? Geological Journal 36, 341-353. DOI 10.1002/gj.883

TwitcheTt, R.J. 2006. The palaeoclimatology, palaeoecology and palaeoenvironmental analysis of mass extinction events. Palaeogeography, Palaeoclimatology, Palaeoecology 232, 190-213. DOI 10.1016/j.palaeo.2005.05.019

TwitchetT, R.J. 2007. The Lilliput effect in the aftermath of the end-Permian extinction event. Palaeogeography, Palaeoclimatology, Palaeoecology 252, 132-144. DOI 10.1016/j.palaeo.2006.11.038

URBANEK, A. 1993. Biotic crises in the history of Upper Silurian graptoloids: a palaeobiological model. Historical Biology 7, 29-50. DOI 10.1080/10292389309380442

VERA, J.A. 2001. Evolution of the South Iberian Continental Margin. Mémoires du Muséum National d'Histoire Naturel de Paris 186, 109-143.

Vera, J.A., Martín-Algarra, A., SÁnchez-GómeZ, M., Fornós, J.J. \& Gelabert, B. 2004. Cordillera Bética y Baleares, 345-464. In VerA, J.A. (ed.). Geología de España, SGE-IGME.

VöRÖS, A. 1993. Jurassic microplate movements and brachiopod migrations in the western part of the Tethys. Palaeogeography, Palaeoclimatology, Palaeoecology 100, 125-145.

DOI 10.1016/0031-0182(93)90037-J

VÖRÖS, A. 2002. Victims of the Early Toarcian anoxic event: the radiation and extinction of Jurassic Koninckinidae (Brachiopoda). Lethaia 35, 345-357.

DOI 10.1111/j.1502-3931.2002.tb00093.x

VÖRÖS, A. 2003. Early Jurassic Koninckinids (Athyridida, Brachiopoda) from Tivoli near Rome, Italy. Geologica Romana 36, 169-197.

VöRös, A. 2005. The smooth brachiopods of the Mediterranean Jurassic: refugees or invaders? Palaeogeography, Palaeoclimatology, Palaeoecology 223, 222-242.

DOI 10.1016/j.palaeo.2005.04.006

Vörös, A. 2009. The Pliensbachian brachiopods of the Bakony Mountains (Hungary). Geologica Hungarica, series Paleontologica 58, 1-300.

VöRös, A. 2016. Early Jurassic (Pliensbachian) brachiopod biogeography in the Western Tethys: The Euro-Boreal and Mediterranean faunal provinces revised. Palaeogeography, Palaeoclimatology, Palaeoecology 457, 170-185.

DOI 10.1016/j.palaeo.2016.06.016

Vörös, A., Kocsis, Á.T. \& PÁlfy, J. 2016. Demise of the last two spire-bearing brachiopod orders (Spiriferinida and Athyridida) at the Toarcian (Early Jurassic) extinction event. Palaeogeography, Palaeoclimatology, Palaeoecology 457, 233-241. DOI 10.1016/j.palaeo.2016.06.022

WADE, B.S. \& OLSSON, R.K. 2009. Investigation of pre-extinction dwarfing in Cenozoic planktonic foraminifera. Palaeogeography, Palaeoclimatology, Palaeoecology 284, 39-46. DOI 10.1016/j.palaeo.2009.08.026

Westermann, G.E.G. 2000. Marine faunal realms of the Mesozoic: review and revision under the new guidelines for biogeographic classification and nomenclature. Palaeogeog- 
raphy, Palaeoclimatology, Palaeoecology 163, 49-68.

DOI 10.1016/S0031-0182(00)00142-5

Wignall, P.B. \& Bond, D.P.G. 2008. The end-Triassic and Early Jurassic mass extinction records in the British Isles. Proceedings of the Geologists' Association 119, 73-84.

DOI 10.1016/S0016-7878(08)80259-3

Wignall, P.B., Newton, R.J. \& Little, C.T.S. 2005. The timing of paleoenvironmental change and cause-and-effect relationships during the Early Jurassic mass extinction in Europe. American Journal of Science 305, 1014-1032. DOI 10.2475/ajs.305.10.1014

Zakharov, V.A., Shurygin, B.N., IL'INA, V.I. \& NikitenKo, B.L.
2006. Pliensbachian-Toarcian biotic turnover in North Siberia and the Arctic Region. Stratigraphy and Geological Correlation 14, 399-417. DOI 10.1134/S0869593806040046

ZeZinA, O.N. 2008. Biogeography of the recent brachiopods. Paleontological Journal 42, 830-858.

DOI 10.1134/S0031030108080078

Zhang, Y., Shi, G.R., He, W., Wu, H., Lei, Y., Zhang, K., Du, C., YANG, T., Yue, M. \& XiAO, Y. 2016. Significant pre-mass extinction animal body-size changes: Evidences from the Permian-Triassic boundary brachiopod faunas of South China. Palaeogeography, Palaeoclimatology, Palaeoecology 448, 85-95. DOI 10.1016/j.palaeo.2015.11.020 